Zabytkoznawstwo i Konserwatorstwo XLIII, Toruń 2012

Agata Warszewska-Kołodziej

Studia doktoranckie z zakresu nauk o sztuce, UMK w Toruniu

\title{
Materiały i konstrukcja wybranych reliefów Henryka Stażewskiego
}

omiędzy nami a natura, a raczej pomiędzy nami, a naszą własną
9,wiadomością istnieje nieprzenikniona zasłona, która ukrywa nam świat i nie pozwala widzieć go w jego właściwej formie. Tą zasłoną jest racjonalistyczne i praktyczne ujmowanie zjawisk. Wskutek tego świat widzimy w schematycznych, szablonowych kształtach i barwach.

Jak usunąć tę zasłonę?

Stać się to może tylko przez odprzedmiotowienie natury, niewidzenie przedmiotu, a ujawnianie tego, co kryje się pod zewnętrzną jego powłoka, mianowicie malarskiej jego strony: stosunków i proporcji kształtów i barw".

Zasady obowiązujace w malarstwie abstrakcyjnym, sa według Henryka Stażewskiego takie same, jak we wszystkich wcześniejszych kierunkach malarstwa. Opierają się na rozwijaniu zagadnień równowagi linii, kolorów i płaszczyzn. W abstrakcji, te same cele realizuje się jednak za pomocą innych, nowych metod kształtowania formy. Zawartość obrazów abstrakcyjnych jest sumą wrażeń i obserwacji świata zewnętrznego, a nie ukazaniem jego zewnętrznego wyglądu. Te bezprzedmiotowe dzieła zachowuja jednak ścisły kontakt z zastaną rzeczywistością, ponieważ stanowią zapis istoty realnych rzeczy i zjawisk.

1 H. Stażewski, Nowa sztuka, a spuścizna squtuki epok minionych, Pion, 1933, nr 5, s. 4, [w:] J. Ladnowska, Z. Karnicka, J. Janik (red.), Henryk Stażewski 1894-1988: w setna rocznice urodz̧in, Muzeum Sztuki w Lodzi, 13 grudnia 1994 - 26 lutego 1995, s. 72. 
Sztuka abstrakcyjna, wynika z doświadczeń swego czasu, w którym człowiek ma częstszy i bliższy kontakt z otaczającymi go geometrycznymi kształtami, liniami prostymi i łukami, niż z przyroda. Dynamizm i szybkie tempo urbanistycznego życia, przenikają do świadomości artysty, wywołując potrzebę przedstawiania rzeczy w ich skrótowej formie, istocie, odrzucając wszelkie zbędne opisy²

Henryk Stażewski uważa, że sztuka abstrakcyjna jest efektem wszechstronnego badania ${ }^{3}$. Jej celem jest ukazanie stanu harmonii i równowagi elementów składowych oraz osiagnięcie organicznej jedności dzieła. Jest to sztuka łącząca czynnik emocjonalny i rozumowy. Artysta opiera się na prawach nauki, ale przede wszystkim korzysta z własnej intuicji, która pozwala mu wzbogacać sztywne reguły i odkrywać rzeczy, dla nauki jeszcze nieodkryte ${ }^{4}$.

\section{Pierwsze reliefy}

W roku $1956^{5}$ Henryk Stażewski, będąc po sześćdziesiątce, dokonał w swej twórczości przełomowej zmiany - zaczął tworzyć reliefy. Pojawienie się w dorobku artysty prac malarskich, w których trzeci wymiar stał się faktem, zapowiadały, pochodzace $z$ lat 30, obrazy o bogatej fakturze. Sa to prace, w których powierzchnie gładkie zestawiono z powierzchniami chropowatymi, a faktura wykonana została z grubej warstwy farby. Wtedy, jednak zagadnienie rzeczywistego wprowadzenia przestrzeni do obrazów zostało przez artystę porzucone, nie doczekało się większego rozwinięcia. Dopiero w latach 50. twórca powrócił do tematu, tym razem maksymalnie go zgłębiając, co zaowocowało nowymi, istotnymi rozwiązaniami formalnymi. Stosowana w tym czasie faktura była bardziej wypukła, powstała przez połączenie farb z różnymi dodatkami, np.: piaskiem, koralikami, żwirem, trocinami, fasola. Jednak na tym artysta nie poprzestał. Dążąc do uzyska-

2 H. Stażewski, (Sztuka abstrakcyjna) 1952-1953, [w:] ibidem, s. 85.

3 H. Stażewski, O sz̨tuce abstrakcoyjnej, Blok, Kurier Bloku, 1924, nr 8-9, s. 6, [w:] ibidem, s. 60.

${ }^{4}$ H. Stażewski, Epigoni moderniżmu i krytycy rutyniści, Wiadomości Literackie, 1933, nr 32, s. 4, [w: ibidem, s. 74 .

5 Wszystkie publikacje podaja datę 1957, jednak Relief w btekeicie i fiolecie na odwrociu ma rok 1956. 
nia większej przestrzenności wybranych elementów kompozycji, całkowicie wyodrębnił formę geometryczną z tła obrazu ${ }^{6}$. Na podłoże, zaczął naklejać płaskie elementy. W początkowych pracach pojawiają się różne warianty połączenia nowych elementów i faktury, np. pokrywanie ich faktura lub zastawienie jednego z drugim.

Wczesnym reliefem H. Stażewskiego jest pochodząca z 1956 roku Komposycja w btekicie i fiolecie. Praca ma kształt pionowego prostokata o niewielkich rozmiarach (z ramą $33,7 \times 26,5 \mathrm{~cm}$, bez ramy $32 \times 25,3 \mathrm{~cm}$ ).

Kompozycję dzieła tworzy siedem przestrzennych elementów, dopełnionych przez figury płaskie, namalowane w partii tła. Elementy przestrzenne o zróżnicowanych kształtach zamykają kompozycję z każdej strony niemal w całości. Artysta posłużył się zarówno liniami prostymi, jak i łukami, które dodały reliefowi subtelnej delikatności.

Kolorystyka pracy jest stonowana, utrzymana w fioletach i różach, akcent stanowią trzy błękitne figury. Plamy barwne sa płaskie i jednolite. W partii tła gdzieniegdzie można odnaleźć ciemnoszary kontur.

Wszystkie figury wzajemnie ze sobą koresponduja zbliżonym kształtem lub kolorem, takich powiązań możemy dostrzec bardzo wiele.

$\mathrm{Na}$ odwrociu znajduja się inskrypcje twórcy - podpis i rok powstania pracy, oraz inskrypcje dodane później: imię i nazwisko autora, tytuł pracy, rok powstania, technika, wymiary.

Praca posiada olejna warstwę malarska. Podłoże stanowi płyta pilśniowa o grubości $0,3 \mathrm{~cm}$, licem jest gładka strona. Na płytę naklejone zostały kształty wycięte $z$ tektury o grubości $0,2 \mathrm{~cm}$. Po uzyskaniu pożądanego układu elementów, całość od strony lica zagruntowano na biało, następnie naniesiono warstwę malarska. Artysta $\mathrm{z}$ wielką precyzją dobierał sąsiadujące ze sobą kolory, niekiedy zmieniał również zdanie, wprowadzając do kompozycji poprawki. O tym, że miało to miejsce również w tym reliefie świadczą obce barwy, widoczne na brzegach płyty - spod różowo-fioletowego koloru wychodzi cieplejszy róż. Po zamocowaniu ramy twórca dokonał prawdopodobnie kolejnej korekty - jasnym, mlecznym laserunkiem. Fotografia wykonana w IR wykazała, że zmieniona została także kompo-

${ }^{6}$ H. Ptaszkowska, Droga Stażenskiego, [w:] Henryk Stażewski, Muzeum Sztuki w Lodzi, Wystawa grudzień 1969 - styczeń 1970, s. 9. 
zycja. Początkowo w partii tła, w lewym górnym narożniku znajdował się jeszcze jeden trójkąt.

Artysta wykończył relief prosta ramą, dopasowaną kolorystycznie do całości. Została ona wykonana z drewnianych listew w kształcie kątowników. Podobnie jak relief najpierw była zagruntowana na biało, później pokryta jasnoszara, olejną warstwą malarską.

H. Stażewski prowadząc badania nad uchwyceniem i organizacja przestrzeni, stopniowo zwiększał w swych dziełach efekt trójwymiarowości. Po etapie naklejania na płaszczyznę płaskich figur wyciętych z tektury, stosował elementy z płyty sklejki, a w końcu klocki wycinane $z$ drewna. Zabiegi te miały związek z przekonaniem, iż przestrzeń można ukazać jedynie za pomoca ruchu. Ruch pojawia się w reliefach na kilka sposobów.

Prace posiadające elementy przestrzenne ulegaja zmianom zarówno w wyniku różnego oświetlenia (gra światła i cieni) jak i w efekcie ruchu odbiorcy. Kiedy widz przemieszcza się, wypukłe figury zasłaniają część płaszczyzny, co powoduje wagledny ruch obrazu ${ }^{7}$. Im bardziej wypukłe elementy, tym zjawisko to jest wyraźniej widoczne.

Artysta stopniowo upraszczał elementy kompozycji, aż doszedł do form pozbawionych wszelkich cech indywidualnych. Zaczął budować prace z powtarzających się, podobnych figur. W ten sposób wszystkie elementy kompozycji stały się równie ważne i mogły ukazywać ruch uchwycony w pewnej fazie, jednej z wielu. Kompozycja nie miała być efektem końcowym, lecz układem zatrzymanym w ruchu. Różnorodne kształty powstawały z wielu powtarzających się elementów, razem tworzacych pewną przestrzeń ${ }^{8}$.

Reliefem, który powstał na tym etapie rozważań nad przestrzenią jest Kompozycja abstrakcyjna (jednotonowa), wykonana w roku 1958. Praca posiada niewielkie rozmiary $31 \times 45,3 \mathrm{~cm}^{9}$. Podłoże ma kształt prostokata poziomego.

K. Kulicz, Ta sztuka chce uyrażać ruch i præestrzeń - Henryk Stażenskei, Rozmawiamy z laureatami Nagród Ministra Kultury i Sztuki, Stolica, 1965, nr 34, s. 4, [w:] Henryk Stażenski malarstwo z lat 1923-1974, katalog wystawy ZPAP, BWA, Lódź, 26 lipiec - 18 sierpień 1974, s. 10.

8 Ibidem.

9 Obraz prawdopodobnie wcześniej był mierzony w ramie, stąd inny rozmiar pracy zapisany na naklejkach, znajdujących się na odwrociu. 
Kompozycję tworzy trzydzieści pięć podobnych elementów, prostopadłościanów o różnej wielkości, umieszczonych na monochromatycznym, jasnofioletowym tle. Bryły pokryto na wszystkich widocznych bokach jasna, szarą warstwą malarską. Ułożone są one po przekątnej, przechodzącej od dołu strony lewej, do góry prawej. W kompozycji przeważają kierunki pionowe.

Elementy przestrzenne, których wielkość jest zróżnicowana, można ogólnie podzielić na małe i duże, ponieważ różnica między mini jest wyraźna. Ułożono je w czterech zbiorach - dwóch zbiorach elementów dużych i dwóch elementów małych. Dodatkowo twórca połączył zbiory w taki sposób, że jeden zbiór elementów dużych przylega do jednego zbioru elementów małych. Figury znajdujące się po stronie lewej położone są niżej, sa mniejsze i zajmuja mniejsza powierzchnię. Te, po prawej ułożone są bliżej środka kompozycji. Zaczynając od strony lewej, Pierwszy zbiór elementów składa się z ośmiu brył, podobnie drugi, trzeci z jedenastu, ostatni również z ośmiu. Bryły duże i jednocześnie bardziej wypukłe znajdują się w zewnętrznej części kompozycji - po lewej i prawej stronie. Małe, umieszczone w centrum, rozchodzą się ku górze. Dodatkową wartość stanowi niepowtarzalna gra cieni rzucanych przez trójwymiarowe formy, zmieniająca się wraz ze zmianą oświetlenia. Zestawienie elementów geometrycznych o wyraźnie różnej, skontrastowanej wielkości, wprowadza do kompozycji element ruch ${ }^{10}$.

Relief wykonano z płyty pilśniowej o grubości $0,4 \mathrm{~cm}$, lico stanowi gładka jej strona. Bryły zostały wycięte $z$ drewna i przyklejone do lica klejem. Występują w ośmiu wielkościach. Po opracowaniu kompozycji - przymocowaniu elementów przestrzennych, lico zagruntowano na biało, po czym naniesiono olejną warstwę malarską. Pierwotnie relief oprawiony był w prostą ramę, wykonana z drewnianych listewek, pomalowanych na jasny kolor ${ }^{11}$.

Obecnie praca nie posiada wszystkich elementów kompozycji - brakuje dwunastu figur. Drewniane klocki samoistnie odpadły i uległy zgubieniu.

10 B. Kowalska, Henryk Stąènski, Warszawa, Arkady 1985, s. 29.

11 Świadczy o tym fotografia reliefu zamieszczona w katalogu z wystawy, [w:] Wystawa prac Henryka Stażewskiego maj 1959, Galeria Kordegarda, Warszawa. 
Nastapiło to dość szybko, o czym świadczy fotografia z kary inwentarzowej założonej w 1969 roku, na której widać, że brakuje jedenastu. Fotografia obrazu w nienaruszonym stanie znajduje się w katalogu z wystawy prac H. Stażewskiego, która odbyła się w Galerii Kordegarda w maju 1959 roku. Obecnie relief nie posiada również ramy.

\section{Wzbogacanie przez upraszczanie}

Stopniowe porządkowanie, upraszczanie elementów składowych reliefów, doprowadziło H. Stażewskiego do stosowania powtarzających się modułów o kształcie prostokąta czy kwadratu. Posługując się modułem, na początku lat sześćdziesiątych artysta zaczął tworzyć prace seryjnie. Operując tymi samymi metodami, badał konkretne zagadnienie na wiele sposobów ${ }^{12}$.

$\mathrm{Na}$ przełomie lat 1959 i $1960 \mathrm{w}$ reliefach pojawily się nowe formy modułowe: prostokat o zaokraglonych narożnikach, prostokąt o wypukłych dłuższych brzegach - tzw. forma beczutkowata. Niekiedy artysta stosował także formy o rzucie koła, później czworoboczne asteroidy (kwadrat o wklęsłych bokach). Prace z tego czasu mają oszczędną kolorystykę, w dużej serii białych reliefów ograniczoną do minimum.

Badanie relacji, pomiędzy poszczególnymi elementami kompozycji oraz między nimi a tłem i otaczająca przestrzenia, było celem tych monochromatycznych dzieł. Wzajemne ułożenie elementów nie określała żadna zasada, a raczej intuicja artysty. M. Tchorek określa dzieła Stażewskiego, jako obrasy możliwe lub potencjalne. Zwraca uwagę na „niedomkniętą kompozycję prac i otwartość na inne obrazy" ${ }^{\prime 3}$, przez co powstaje pojęcie serii, w którym poszczególne prace dopełniają się wzajemnie.

Białe reliefy zbudowane są z maksymalnie neutralnych elementów składowych: białych modułów najczęściej form beczułkowatych, często ograniczających się do dwóch, (w reliefach późniejszych również asteroidów)

12 W. Borowski, Stażenskei 1969, [w:] Henryk Stażenski, Muzeum Sztuki w Lodzi grudzień 1969 - styczeń 1970, s. 14.

13 A. Turowski, oprac. M. Jurkiewicz, J. Mytkowska, W. Borowski, Henryk Stażenski: ekonomia myślenia i postrzegania, Warszawa 2006, s. 15. 
oraz białego tła. Mimo, iż prace te sa tak proste, ascetyczne posiadają pewien łatwo zauważalny urok, wdzięk, są bardzo subtelne i zarazem wysublimowane ${ }^{14}$.

Przykładem takiego reliefu jest praca pochodzaca z 1964 roku, o znacznych rozmiarach: $300 \times 500 \mathrm{~cm}$, jedna z największych $\mathrm{w}$ dorobku artysty. Jej podłoże ma kształt poziomego prostokąta.

Relief tworza trzy wielkie beczułkowate formy (ok. $130 \times 80 \mathrm{~cm}$ ) i osiem znacznie mniejszych czworobocznych asteroidów $(25 \times 25 \mathrm{~cm})$. Formy beczułkowate znajdują się blisko siebie. Są bardziej wypukłe niż elementy małe. Ustawiono je pod różnym kątem, dwie górne zbliżone sa do pionu, dolna do pozycji poziomej. Pierwsza 'beczka' od lewej znajduje się nieco niżej od drugiej. Pod drugą ułożona jest trzecia leżącą forma, która dotyka jej podstawy narożnikiem. Pierwsza i trzecia przechylają się w prawo, pod tym samym katem. Asteroidy umieszczone zostały w dolnej połowie pracy. Wychodza jakby z lewych dolnych narożników pionowych 'beczek' i zmierzaja w kierunku lewego, dolnego narożnika reliefu. Cztery z nich stykają się narożnikami.

Podłoże obrazu stanowi skrzynia zbudowana ze sklejki, która wewnątrz posiada z pewnością dodatkową konstrukcję wzmacniająca. Grubość skrzyni wynosi $10 \mathrm{~cm}$. Przednia ściana stanowiaca lico, prawdopodobnie tak samo jak tylna, została zbudowana z ośmiu płyt połączonych w całość. Zarówno duże formy beczułkowate, jak i mniejsze asteroidy wycięto ze sklejki o grubości ok. 1,2 cm. Elementy przestrzenne przymocowano do lica za pośrednictwem dość wysokich drewnianych klocków, o kwadratowym rzucie, przybitych gwoździami do podłoża. Duże elementy są przymocowane na czterech, mniejsze na jednym wsporniku. Całość ( $z$ dwóch stron) pokrywa biała warstwa malarska.

W reliefach z tego czasu pojawia się po raz pierwszy istotne i ciekawe zjawisko, które dotyczy niemal całego późniejszego dorobku H. Stażewskiego. Polega ono na zlecaniu osobom postronnym wykonania dzieła

14 J. Ładnowska pisze, że białe reliefy maja, nieoczekiwanie jak u Arpa, własna, niepowtarzalna poetykę, J. Ladnowska Sztuka wolnego tadu, [w:] J. Ladnowska, Z. Karnicka, J. Janik (red.), Henryk Stażenski 1894-1988: w setna rocznice urodzin, Muzeum Sztuki w Lodzi, 13 grudnia 1994 - 26 lutego 1995, s. 23. 
sztuki lub jego części, oczywiście na podstawie projektu twórcy. Według J. Ludwińskiego Henryk Stażewski, był pierwszym artystą w Polsce, który stosowal tego typu zabieg ${ }^{15}$.

\section{Reliefy metalowe: aluminium, miedź}

Po doświadczeniach z ascetycznymi reliefami, uwagę twórcy przykuło zjawisko światła przesuwającego się po przestrzennym obiekcie. Aby zwiększyć w swych pracach zakres jego działania w roku 1964 po raz pierwszy użył do budowy reliefów polerowanego metalu: miedzi i aluminium. „Daje on większą czystość w obserwowaniu ruchu form powstającego w reliefie w skutek ruchu widza. Równocześnie metal ostrzej reaguje na światło, które jest podstawowym składnikiem moich obrazów. Właściwa forma istnieje tylko wraz z cieniem, który jest jeszcze jednym jej powtórzeniem i bardzo ważnym czynnikiem zmienności obrazu ${ }^{16 "}$. Wśród nowych reliefów pojawiają się również prace, w których ruch przedstawiony jest dosłownie - mobile napędzane silnikiem elektrycznym.

Relief różouy, posiada numer 28-1965 (porządkowy numer obrazu wykonanego w ramach danego roku ${ }^{17}$ ). Podłoże pracy ma kształt pionowego prostokata o wymiarach $62 \times 51 \mathrm{~cm}$, od strony lica pełni ono funkcje obramowania. Do podłoża w pewnej odległości przymocowany został nieco mniejszy prostokat $(48 \times 36 \mathrm{~cm})$, wycięty $\mathrm{z}$ metalu - prawdopodobnie jest to właściwe tło kompozycji. $\mathrm{Na}$ nim centralnie, niemal równolegle do pionowej osi podłoża, umieścił artysta sześć prostokątów $\left(12 \times 8,6 \mathrm{~cm}^{18}\right)$, o lekko wklęsłych dłuższych bokach. Moduły te, ułożone są względem

15 J. Ludwiński, Epoka błekitu, Kraków: Otwarta Pracowania, 2003, s. 115.

${ }_{16}$ H. Stażewski, (wypowiedź autora), Odra, 1968, nr 2, s. 63-68, [w:] J. Ladnowska, Z. Karnicka, J. Janik (red.), Henryk Stażenski 1894-1988: w setnq rocznice urodzin, Muzeum Sztuki w Lodzi, 13 grudnia 1994 - 26 lutego 1995, s. 89.

17 System numeracji dzieł artysta stosuje od końca lat pięćdziesiątych, w publikacji: J. Ladnowska, Z. Karnicka, J. Janik (red.), Henryk Stażenskei 1894-1988: w setna rocznice urodzin, Muzeum Sztuki w Lodzi, 13 grudnia 1994 - 26 lutego 1995, s. 129, jako prawdopodobna data wprowadzenia przez artystę systemu numeracji prac, podany jest rok 1957.

18 Wszystkie podawane wymiary form beczułkowatych i czworobocznych asteroidów dotyczą ich osi symetrii. 
siebie pod różnym kątem: cztery z nich zbliżają się do pionu, dwa górne do osi poziomej. Trzy elementy w centralnej części kompozycji są bardziej wysunięte do przodu i częściowo przykrywaja pozostałe. Układ dwóch górnych modułów ułożonych centralnie jest powtórzony przez sąsiednie elementy znajdujace się po lewej stronie.

Mocny akcent kolorystyczny kompozycji stanowi czarne obramowanie. Połączenie łososiowo-różowej barwy tła oraz jasnych, aluminiowych modułów jest stonowane i harmonijne. Ślady po polerowaniu na prostokątnej blasze układają się poziomo, na większości modułów, oprócz dwóch.

$\mathrm{Na}$ odwrociu znajduja się inskrypcje: podpis twórcy, numer porządkowy pracy i rok jej powstania oraz rozmiar reliefu, dotyczacy tylko metalowej części. Widocznie czarny fragment podłoża został potraktowany przez artystę jak rama.

Podłoże wykonane jest z płyty pilśniowej $(62 \times 51 \times 0,3 \mathrm{~cm})$, lico stanowi jej gładka strona. Do płyty od odwrocia, wzdłuż boków przybito drewniane listewki o szerokości 2,5 cm i wysokości ok. $1 \mathrm{~cm}$, połączone w narożnikach przez ścięcie pod kątem ok. 45. Od strony lica, do podłoża przymocowana jest konstrukcja wykonana z drewnianych listew, być może coś w rodzaju kratownicy, o wysokości ok. 2,5 cm. Jest ona mniejsza o ok. $2 \mathrm{~cm}$ (z każdej strony), od leżącej na niej blachy. Konstrukcję przymocowano na brzegach do plyty pilśniowej od odwrocia, za pomoca dziesięciu śrub. Widoczna z przodu część podłoża, jego boki i listwy pod blachą pokryte zostały czarna warstwą malarską (emulsyjną albo akrylowa). $\mathrm{Na}$ drewniana konstrukcję nałożono blachę - polerowana płytę aluminiową (o grubości $1 \mathrm{~mm}$ ), fabrycznie lakierowaną na kolor. Przymocowano ja czterema śrubami, w miejscach ukrytych pod elementami kompozycji. Do blachy przykręcono od dołu metalowe wsporniki dla elementów modułowych. Wyższe to metalowe ceowniki (wysokość 3,3 cm), niższe - profile kwadratowe (wysokość 2,1 cm). Elementy modułowe wycięte z polerowanej aluminiowej blachy (o wymiarach $12 \times 8,6 \mathrm{~cm}^{19}$ i grubości $0,1 \mathrm{~cm}$ ) 11 przyklejono do podstawek klejem syntetycznym.

19 Wszystkie podawane wymiary form beczułkowatych i czworobocznych asteroidów dotyczą ich osi symetrii. 
Prawdopodobnie proces montowania części reliefu przebiegał w następującej kolejności. Najpierw do różowej blachy przykręcono metalowe wsporniki śrubami (od odwrocia), następnie blachę połączono z jej podstawą (kratownica), również za pomocą śrub (wkręconych od lica). Miejsca otworów i śrub ukryte zostały pod elementami modułowymi. Tak przygotowany fragment dzieła, przykręcono do podłoża - od odwrocia. Na końcu przyklejone zostały ma klej syntetyczny elementy modułowe. Być może jedynie ostatni etap prac - zamontowanie metalowych figur - wykonał sam artysta, a reszta konstrukcji powstała na zamówienie, według jego projektu. Sugerować może to fakt, iż ułożenie wsporników nie pokrywa się z ułożeniem modułów, co uwidacznia się w odpowiednim oświetleniu. Ponieważ blacha lekko się powyginała, ułożenie wsporników można odczytać na powierzchni metalowych elementów.

Relief 32 ( $\mathrm{nr}$ 32-1964) w kolorze miedzi, o wymiarach $40 \times 40 \mathrm{~cm}$, składa się z podłoża i elementów modułowych - form beczułkowatych i czworobocznych asteroidów. Wszystkie elementy zarówno płyta podłoża jak i moduły zostały wykonana $z$ materiału imitującego miedziana blachę - laminatu foliowanego miedzią. Kompozycję tworzą trzy duże elementy beczułkowate $(19,5 \times 9,3 \mathrm{~cm})$ i dwadzieścia siedem znacznie mniejszych asteroidów (ok. 2,4 × 2,4 cm). Ułożenie 'beczek' zbliżone jest do osi pionowej: pierwsza od lewej strony odchylona jest w lewo, środkowa ustawiono w pionie, ostatnia delikatnie odchylona jest w prawo. Elementy stopniowo schodza ku dołowi. Mniejsze czworoboczne asteroidy rozmieszczone są nieregularnie zarówno na płycie podłoża, jak i na formach beczułkowatych. Na pierwszej 'beczce' od lewej umieszczone zostały trzy asteroidy (dwa stykające się), na drugiej dwa, na trzeciej jeden. Znajdujace się na podłożu małe figury, często połączone są w zbiory dwu-, trzyi czteroelementowe, w których stykają się narożnikami.

$\mathrm{Na}$ odwrociu artysta umieścił inskrypcje: podpis, numer porządkowy i rok powstania reliefu oraz rozmiar pracy.

Podstawa reliefu została wykonana $z$ płyty sklejki (o wymiarach $39 \times 39 \times 1 \mathrm{~cm}$ ), na której zamontowano (przybijając gwoździami) dwie drewniane, pionowe listwy. $Z$ drugiej strony przyklejono klejem, prawdopodobnie stolarskim, płytę laminatu (o grubości $0,15 \mathrm{~cm}$ ), większą od sklejki o centymetr z każdej strony. Zastosowana płyta to laminat foliowany 
miedzią ${ }^{20}$ wykorzystywany powszechnie do obwodów drukowanych. Małe elementy - czworoboczne asteroidy (o wymiarach ok. 2,4 $\times 2,4 \mathrm{~cm}$ ), przyklejone są do podłoża za pośrednictwem wsporników o wysokości ok. $1 \mathrm{~cm}$. Większość z nich wykonana została z drewna, niektóre z płyty pilśniowej. Wsporniki chowają się pod asteroidami, są od nich około centymetr mniejsze. Elementy umieszczone na formach beczułkowatych posiadaja niższe podstawy, ich wysokość to ok. $0,2-0,3 \mathrm{~cm}$. Figury beczułkowate zostały zamocowane w ten sam sposób, ale na większych i wyższych klockach (ok. 1,5 cm), każda forma na jednej podstawce. Elementy geometryczne wycięto z takiej samej jak podłoże - płyty laminowanej, oprócz dwóch, które sa wykonane z płyty cieńszej - o grubości $0,1 \mathrm{~cm}$. Większość wsporników jest pokryta warstwą malarską w kolorze miedzi. Dwa asteroidy wykonane z cieńszej płyty, przyklejone sa na wspornikach z płyty pilśniowej, która nie została pomalowana. Prawdopodobnie artysta dodał te elementy w późniejszym czasie. Jeden $\mathrm{z}$ nich znajduje się $\mathrm{w}$ prawym górnym rogu (w zbiorze czterech figur), drugi obok, w centralnej części (w zbiorze trzech).

\section{Kolor}

W roku 1967, może nawet pod koniec 1966, po doświadczeniach z przestrzenią, H. Stażewski skoncentrował swą uwage na problemie koloru. W celu osiagnnięcia czytelnych efektów ponownie sięgnął po rozwiązanie najprostsze. W nowych pracach stosował głównie formę kwadratu (zarówno, jako kształt całości oraz elementów składowych) i trójkąta.

Twórczość artysty z tego okresu, to kolejne serie zróżnicowanych prac, w których zgłębiał właściwości koloru na wszelkie możliwe sposoby. Stosował kontrastowe połączenia barw i kształtów, zestawienia niewielkich powierzchni koloru z jednobarwnym tłem, rozbicie formy kwadratu pokrytego barwą, kompozycje diagonalne wprowadzające napięcie w obrazie ${ }^{21}$.

20 Płyta może być pokryta miedzianą folia z jednej lub z dwóch stron. Ta wykorzystana $\mathrm{w}$ reliefie jest foliowana jednostronnie

21 A. Turowski, oprac. M. Jurkiewicz, J. Mytkowska, W. Borowski, Henryk Staženski: ekonomia myślenia i postreegania, Warszawa 2006, s. 18. 
Jednym z reliefów tej serii, jest zbudowany w schematyczny sposób Relief 29 ( $\mathrm{nr}$ 29-1969). Praca ma kształt kwadratu o rozmiarach $60 \times 60 \mathrm{~cm}$. Artysta zastosował w nim czteropoziomowy układ form. Pierwszym poziomem sa płaskie plamy barwne naniesione na podłoże, drugim - trójkąt wycięty z płyty pilśniowej, przyklejony do podłoża, trzecim - figury geometryczne wycięte z płyty: pięciobok i trójkąt, przymocowane do podłoża za pośrednictwem drewnianych klocków, i w końcu czwartym poziomem są listwy dzielące lico na dwie części.

Kwadrat podłoża został powtórzony w mniejszej skali przez drewniane listwy otaczające centralną część kompozycji. Wypełniono ją trzema przestrzennymi figurami geometrycznymi, umieszczonymi na dwubarwnym podłożu. Pięciobok (zbudowany z kwadratu i trójkąta) w kolorze cieplejszego różu ustawiony diagonalnie, skierowany został jednym z wierzchołków, ku prawemu dolnemu narożnikowi. Przekątna na osi której go umieszczono, zarysowana jest przez prawy bok fioletowego trójkąta. Pięciobok i trójkąt stykają się wierzchołkami. W górnej, centralnej części reliefu znajduje się kolejny trójkąt prostokątny, w kolorze fioletowym, tym razem jednak bezpośrednio naniesiony na podłoże. Ułożenie jego najdłuższego boku pokrywa się z bokiem różowej figury przestrzennej. Na płycie podłoża fragment po stronie prawej, w kształcie trapezu jest w kolorze chodnego różu, pozostała część ma kolor fioletowy, tak jak trójkaty. Listwy otaczające kompozycję pokryte zostały szara warstwą malarska, jedynie ich przednia część jest czarna - stanowi jakby kontur wyznaczający centralną część dzieła. Zewnętrzny fragment podłoża, będący obramowaniem reliefu oraz boki pracy również pomalowano na szaro. $\mathrm{Na}$ odwrociu artysta naniósł inskrypcje: podpis i numer porządkowy $z$ rokiem powstania reliefu.

Tradycyjnie, podłoże reliefu (o grubości $2 \mathrm{~cm}$ ) wykonane zostało z trzymilimetrowej płyty pilśniowej i drewnianych listewek ułożonych wzdłuż brzegów (wys. 1,7 cm, szer. 1,4 cm), przymocowanych z tyłu pracy. Dodatkowo na odwrociu zamocowano również cztery listwy konstrukcyjne, ułożone diagonalnie w narożnikach podłoża (ich długość ok. $38 \mathrm{~cm}$, grubość $1,4 \mathrm{~cm}$ ). Wszystkie elementy przybito gwoździami i przyklejono.

Do lica (gładka strona płyty) przymocowano cztery drewniane listwy (wys. 2,5 cm, szer. 0,9 cm), w odległości ok. $14 \mathrm{~cm}$ od brzegów. Przybi- 
to je od odwrocia - każda w trzech miejscach. Listwy wyznaczyły kwadratowa powierzchnię o wym. $45 \times 45 \mathrm{~cm}$. Przestrzenne figury wycięte zostały z trzymilimetrowej płyty pilśniowej. Dwie - pięciobok i dolny trójkąt przymocowano do podłoża w odległości $1,4 \mathrm{~cm}$, za pośrednictwem drewnianych klocków w kształcie trójkątów. Naniesione elementy zostały przyklejone klejem. Praca w całości najpierw zagruntowana była na biało, następnie pokryta odpowiednimi kolorami farby akrylowej. Farby o spoiwie akrylowym artysta stosował od połowy lat sześćdziesiątych.

Zaglądając pod przestrzenne elementy umieszczone na drewnianych klockach, zauważymy, iż pierwotna kolorystyka podłoża różniła się od obecnej. W zagłębieniach widoczne sa pozostałości koloru jasnozielonego, żółtego i czerwonego. Być może kolorystyka zmieniana była kilkakrotnie. Wskazywać może na to fakt, że czerwona warstwa malarska znajduje się prawdopodobnie na zielonej.

Konstrukcja ostatniego opisanego Reliefu 11 (nr 11-1971) nieco różni się od konstrukcji Reliefu 29, ale pewnie elementy pozostały niezmienione. Jest to praca późniejsza, w której H. Stażewski zrezygnował z umieszczania elementów kompozycji na wspornikach, a zaczął operować płaszczyznami - cofając je lub wysuwając.

$\mathrm{Na}$ powierzchni o kształcie kwadratu (rozmiar pracy wynosi $104,5 \times 104,5 \mathrm{~cm})$ w prawym górnym narożniku, artysta umieścił dwie bryły (równoległoboki) lub dwie płaszczyzny w kształcie kwadratu, wysunięte do przodu, natomiast w lewym dolnym rogu znajduje się płaszczyzna cofnięta. Zarówno dwie bryły, jak i część cofnięta są tej samej wielkości (ok. $35 \times 35 \mathrm{~cm}$ ), a każda z nich stanowi jedną dziewiątą część całości.

Tło kompozycji ma kolor jasnego fioletu. Pierwsza bryła jest szaroróżowa, druga pokrywa ciemniejszy od tła fiolet. Część położona najgłębiej jest intensywnie czerwona, dzięki czemu jakby wychodzi przed lico, jest elementem dominującym, przyciagającym uwage widza. Zastosowane kolory ściśle ze sobą koresponduja. Fioletowa barwa elementu wypukłego nawiazuje do koloru największej płaszczyzny, jest od niego o kilka tonów ciemniejsza. Można również przypuszczać, że barwa elementu szaroróżowego powstała z połączenia czerwonego koloru fragmentu wklęsłego i płaszczyzny jasnofioletowej. 
$\mathrm{Na}$ odwrociu tradycyjnie znajdują się inskrypcje twórcy: podpis - w centralnej kwaterze, numer porządkowy pracy oraz rok jej powstania - w lewym górnym narożniku.

Podłoże wykonane zostało z płyty pilśniowej o wymiarach 104,5 $\times 104,5 \times 0,3 \mathrm{~cm}$, wzmocnionej od odwrocia. Wzdłuż jej boków przymocowano wysokie listwy. W lewym dolnym narożniku płyty wycięty został kwadrat o wymiarach $35 \times 35 \mathrm{~cm}$. Również listwy boczne ścięto o trzy centymetry. W to miejsce, do ściętych listew przyklejona została kwadratowa płyta, ułożona niżej od powierzchni tła o $3 \mathrm{~cm}$. Przestrzeń między płytą tła a położonym głębiej kwadratem uzupełniły listwy konstrukcji wzmacniającej.

Relief od odwrocia wzmocniono konstrukcją wykonana $z$ drewnianych listew (szer. 1,5, wys. 2,5 cm, dl. $102 \mathrm{~cm}$ ), zbudowaną na kształt kratownicy. Dzieli ona powierzchnie podłoża na dziewięć takich samych kwater. Przymocowano ją do płyty przyklejając klejem oraz przybijając od strony lica. Dodatkowo na tę konstrukcje nałożono cztery listwy wzmacniające, umieszczone diagonalnie. Przybito je do zarówno do wnętrza listew bocznych oraz do kratownicy. Wszystkie elementy umieszczone na odwrociu sa niższe od listew bocznych, pozostaja ukryte podczas ekspozycji.

Dwa wysunięte elementy pracy zbudowano z listew (o wysokości $2 \mathrm{~cm}$ ) i kwadratów wyciętych z płyty pilśniowej (takiej samej jak pozostałe części reliefu). Są od siebie konstrukcyjnie niezależne. Wszystko zmontowane jest gwoździami i klejem.

Lico oraz boki, przed nałożeniem warstwy malarskiej, zostały zagruntowane na biało. Artysta zastosował farby o spoiwie akrylowym. Na dużych powierzchniach - tło, dwa górne kwadraty nakładał warstwę malarską wałkiem (charakterystyczna faktura), boki oraz kwadrat dolny pomalowane zostały pędzlem.

\section{Zakończenie}

Do budowy reliefów Henryk Stażewski stosował zróżnicowane materiały: tekturę, drewno, płyty drewnopochodne, metal, tworzywa sztuczne, papier. W pracach tych chęć osiagnięcia konkretnego efektu artystycznego, często 
wiązała się dla twórcy z koniecznością dobrania odpowiednich materiałów oraz właściwego sposobu konstrukcji. Materia, podobnie jak kompozycja czy kolorystyka stała się równoważnym elementem składowym dzieła, środkiem artystycznego wyrazu. Zastosowany materiał mógł istotnie wpływać na charakter pracy, jest tak np. w przypadku reliefów wykonanych z metalu.

„Treść i forma są organiczną nierozłączną całością, stanowią one dwie strony jednej i tej samej rzeczy" - pisał artysta ${ }^{22}$. Poglądy H. Stażewskiego na ten temat pokrywają się z najważniejszymi założeniami sztuki konstruktywistycznej. W teoretycznych założeniach konstruktywizmu ważna rolę odgrywała koncepcja formy. Uważano, że w jej skład wchodzi zespół elementów: materiał nieukształtowany i ukształtowany oraz ich właściwości zmysłowe, tektoniczne i pojęciowe. W konstruktywizmie forma posiada zarówno wartość pojęciowa jak i materialną ${ }^{23}$.

Większość działań artysty oparta była na konsekwencji i modyfikowaniu wcześniejszych rozwiązań. Dobór odpowiednich materiałów, jak i sposób ich łączenia zmieniał się równocześnie z ewolucją jego drogi artystycznej. Rozwojowi i modyfikacji podlegały zarówno elementy tworzące kompozycję, jak i podłoża.

Najwcześniejsze reliefy posiadały podłoże wykonane z płyty pilśniowej, otoczone autorską ramą wykonana $z$ listew. Kolejne serie z modułami beczułkowatymi zwykle miały podłoża wizualnie grubsze. Artysta zrezygnował $w$ nich $z$ ram zastępując je listwami mocowanymi na odwrociu wzdłuz brzegów. W reliefach metalowych płyty metalowe lub laminaty wzmacniane były od odwrocia płytami drewnopochodnymi. Natomiast późniejsze reliefy kolorowe posiadały podłoża modyfikowane zależnie od potrzeb kompozycji, jednak widoczny jest $\mathrm{w}$ nich pewien konstrukcyjny schemat. Pilśniowa płyta od odwrocia zawsze posiada listwy wzdłuż brzegów oraz dodatkowe listwy konstrukcyjne umieszczone w narożnikach.

Podobny rozwój możemy dostrzec w elementach przestrzennych. Początkowo były to płaskie formy wycinane z tektury, później sklejki i drewna,

22 H. Stażewskie, Nowa squtuka, a spuścizna squtuki epok minionych, Pion, 1933, nr 5, s. 4, [w:] J. Ladnowska, Z. Karnicka, J. Janik (red.), Henryk Stażewski 1894-1988: w setna rocznice urodzin, Muzeum Sztuki w Lodzi, 13 grudnia 1994 - 26 lutego 1995, s. 72.

23 A. Turowski, Konstruktywizm polski: próba rekonstrukeji nurtu (1921-1934), s. 119-121. 
naklejane bezpośrednio na tło. Niekiedy artysta nakładał na przestrzenne elementy kolejne. W Reliefach białych i ich modyfikacjach moduły zostały odsunięte od podłoża i mocowane na wspornikach. Podobnie było w reliefach metalowych i kolorowych. Natomiast, na początku lat 70. pojawiły się prace, których przestrzenność wynika nie z nakładania dodatkowych elementów, lecz jakby z przesunięć ich powierzchni.

Zaglądając w głąb reliefów możemy odkryć wiele niespodzianek. Twórca zakładał, że uważny odbiorca będzie oglądał reliefy z różnych stron, że zajrzy również do ich „wnętrza”. Świadczyć może o tym fakt, że pokrywał odpowiednim kolorem także elementy dystansujące - zwykle były to drewniane klocki, schowane pod geometrycznymi figurami. Patrząc na pracę z przodu, elementy te są niewidoczne.

Aby w pełni poznać prace H. Stażewskiego, należy więc skoncentrować się zarówno na ich przekazie, jak i na walorach materialnych. Dlatego zagadnieniem niezwykle interesującym $\mathrm{i}$ istotnym wydaje się identyfikacja poszczególnych materiałów oraz przede wszystkim określenie konstrukcji dzieła. Te dwa elementy, obok pozostałych środków artystycznego wyrazu, także stanowią zapis myśli artysty.

\section{Summary}

\section{Materials and construction of selected reliefs made by Henryk Stażewski}

The first reliefs appeared in the achievements of Henryk Staziewski around 1956. Artist made these objects in large quantities to the mid seventies. Each new series was built in a slightly different way, sometimes with the use of new materials. The kind of material often decides about character of works of art, as it is in metal reliefs. Similarly, a way to combine elements is very significant, for example can makes an impression of mysterious play of light and shadows, especially exposed in the white reliefs. Analyzing the importance of material and structure in the works of Henryk Stażewski, it can be concluded, that these are equivalent to other means of artistic expression, which reflect artist's thoughts.

The essay presents seven reliefs from the subsequent series, focusing primarily on its technical construction. The main aim was to show how the way of performing this works of art had been changing and prove that this was consequent and fluent process, where each component has its origin in the earlier works. 
Knowledge about the used materials and structures let the receivers better know the works of Stażewski and get new information, which are often hidden in them. Looking into the relief we can find many surprises. Artist assumed that accuraterecipient would observe them from different points, reaching even deep inside of it. This is supported by the fact that the layer of color is also on parts hidden under the geometric elements.

Artist often changed his compositions and colors of his works. The remains of his previous actions can sometimes be found under the surface of the paint and sometimes in hollows of relief. 


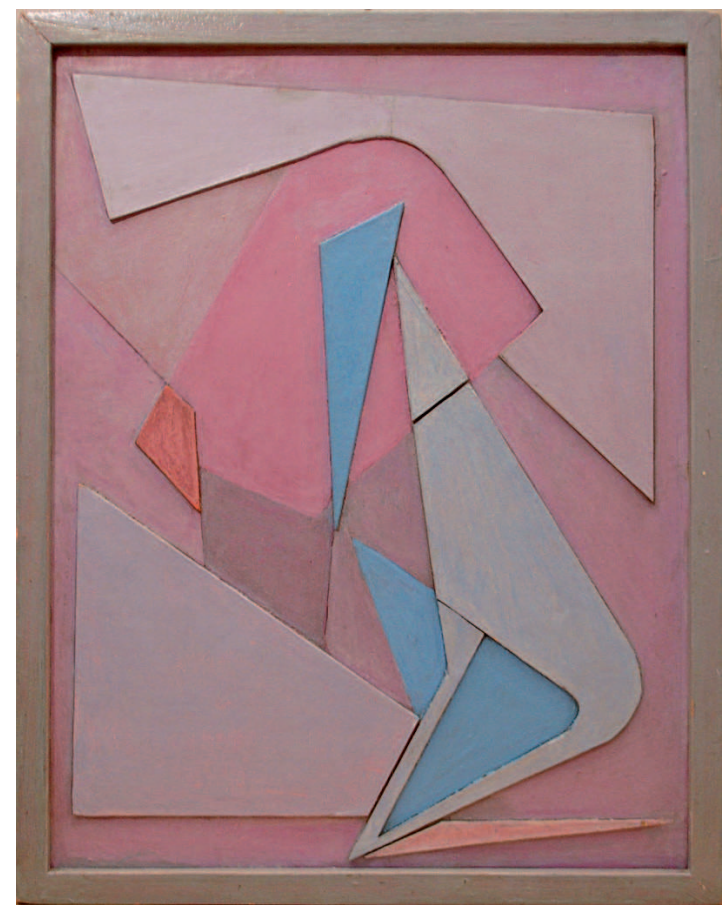

Il. 1. Komposycja w btekicie i fiolecie, 1956 r., Muzeum Narodowe we Wrocławiu

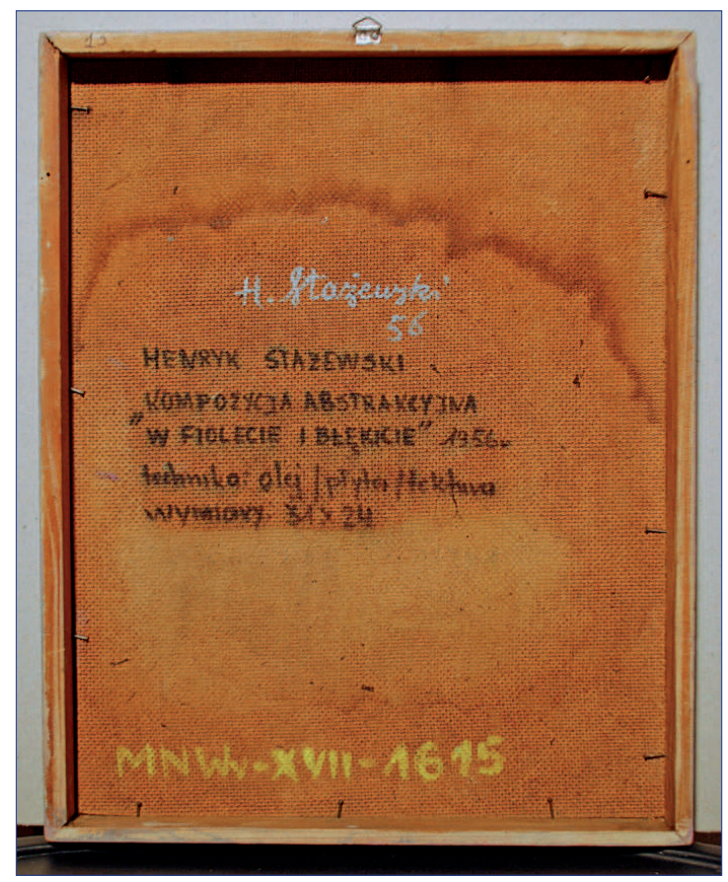

Il. 2. Komposycja w btekeicie i folecie, 1956 r., odwrocie 


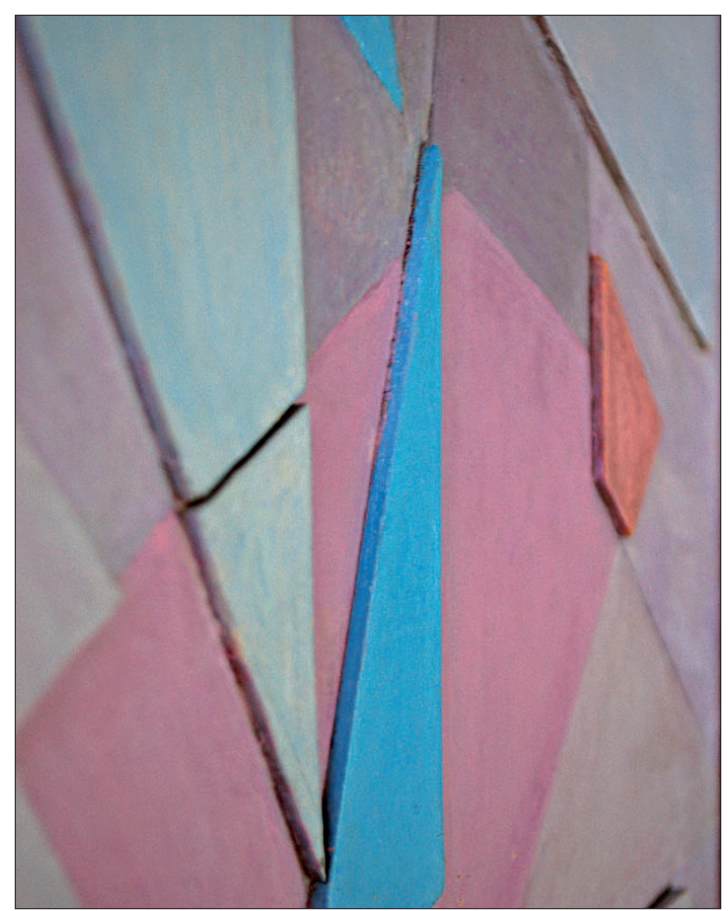

Il. 3. Zbliżenie fragmentu lica

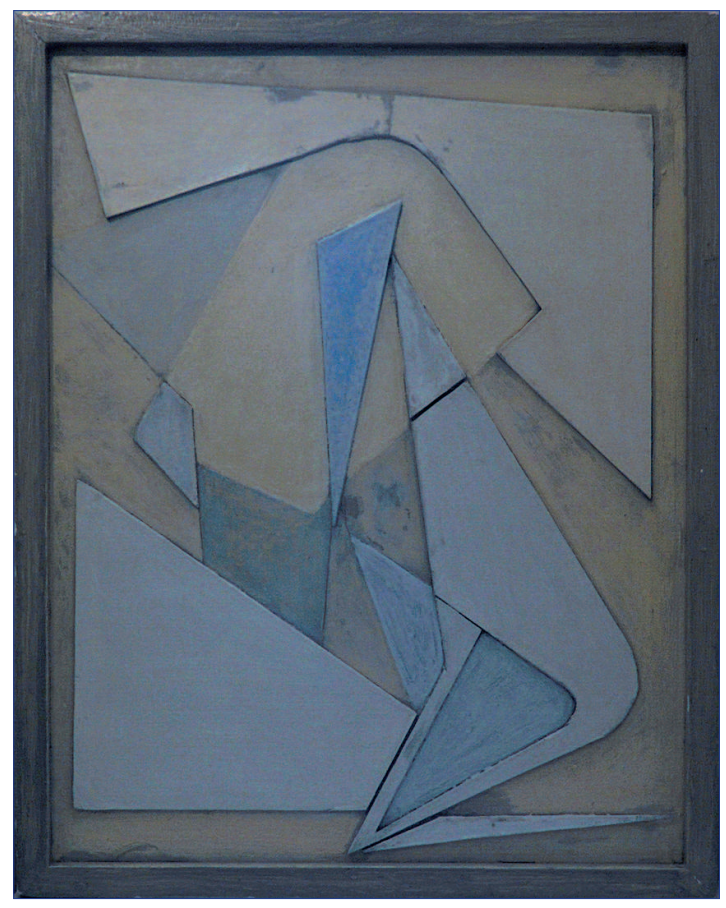

Il. 4. Fotografia Komposycii w btekeicie i fiolecie $\mathrm{w}$ świetle podczerwonym 


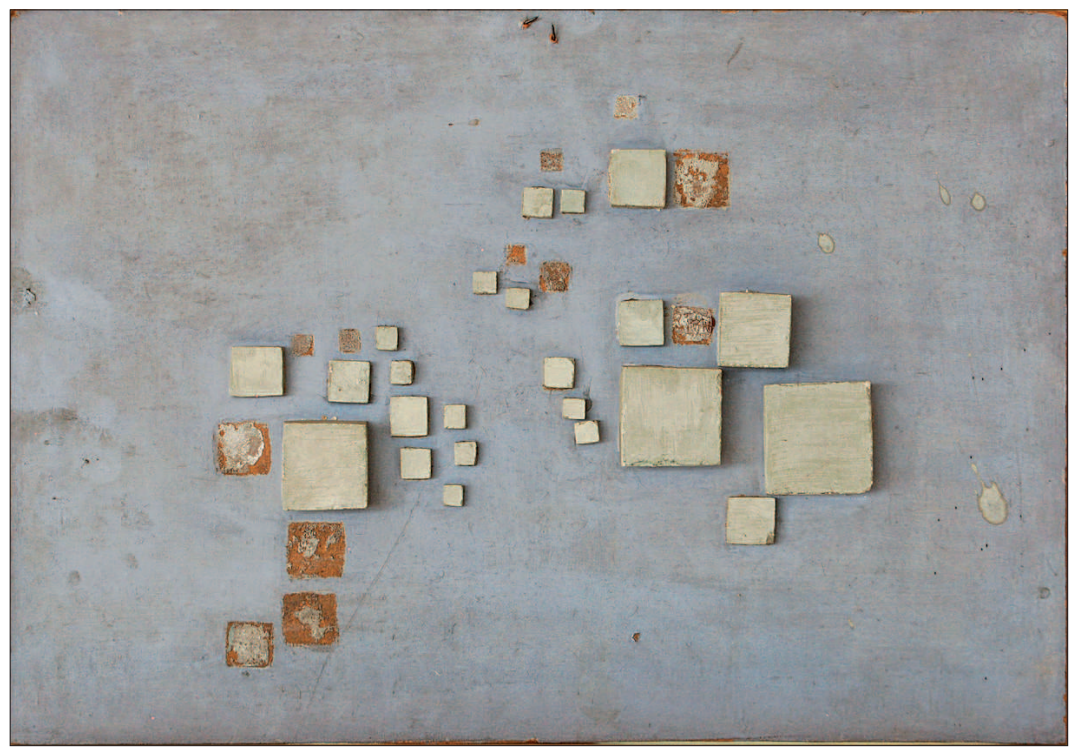

Il. 5. Kompozycja abstrakcyjna, 1958 r., Muzeum Śląska Opolskiego w Opolu

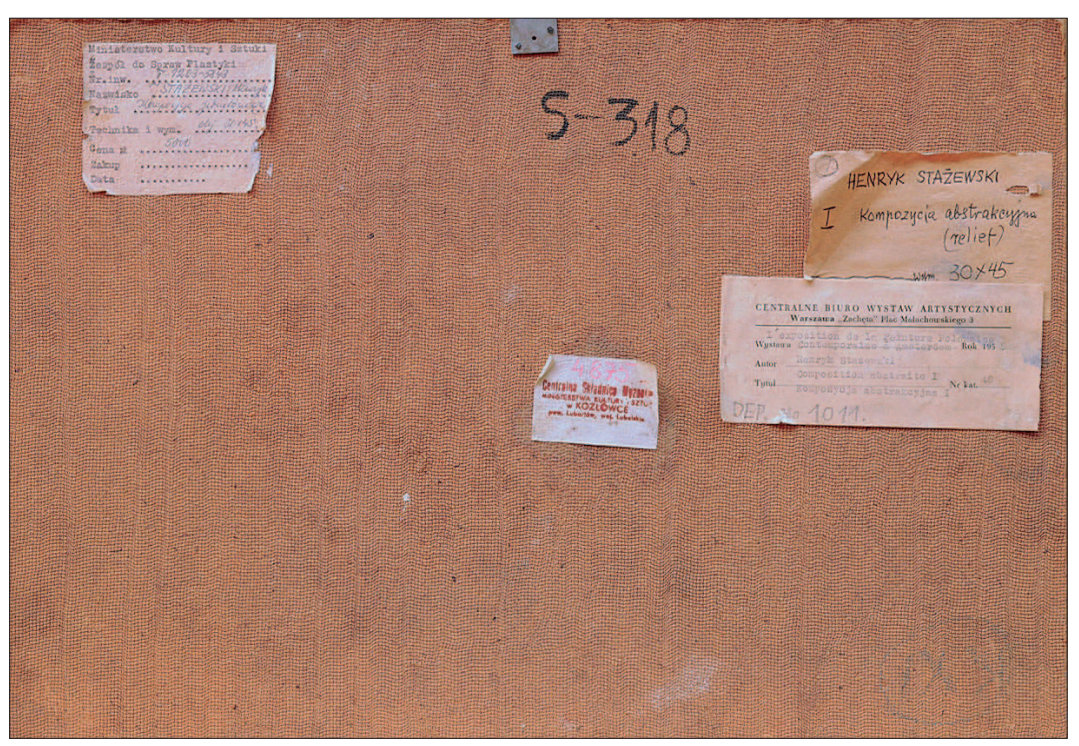

Il. 6. Kompozycja abstrakcyjna, odwrocie 


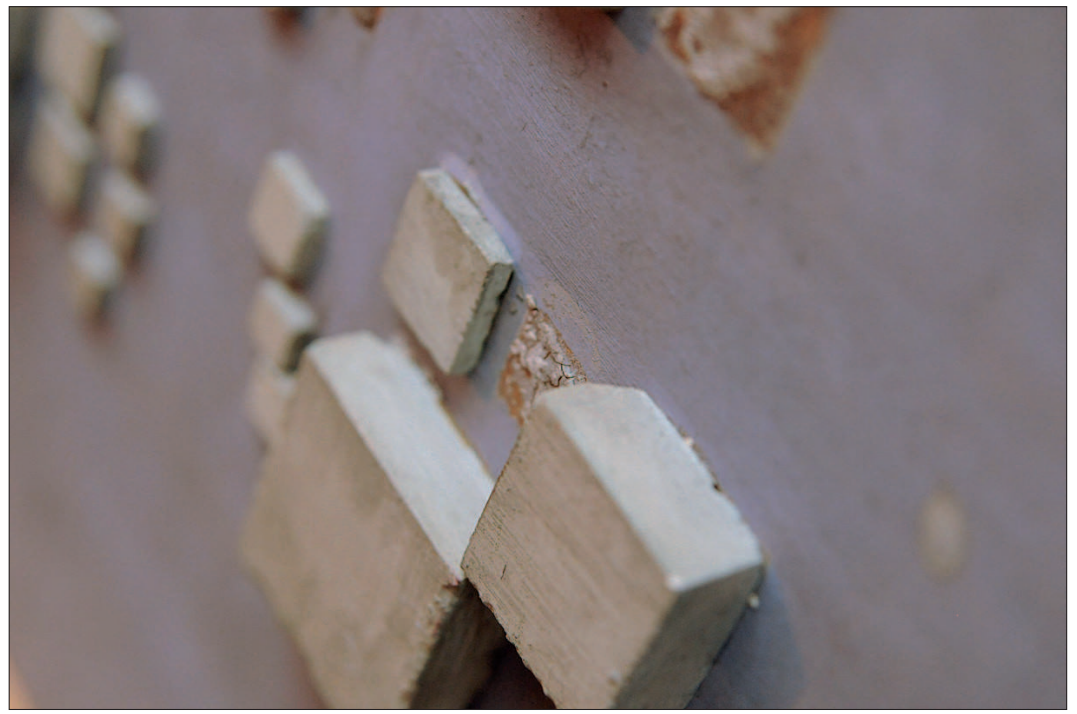

Il. 7. Zbliżenie fragmentu lica

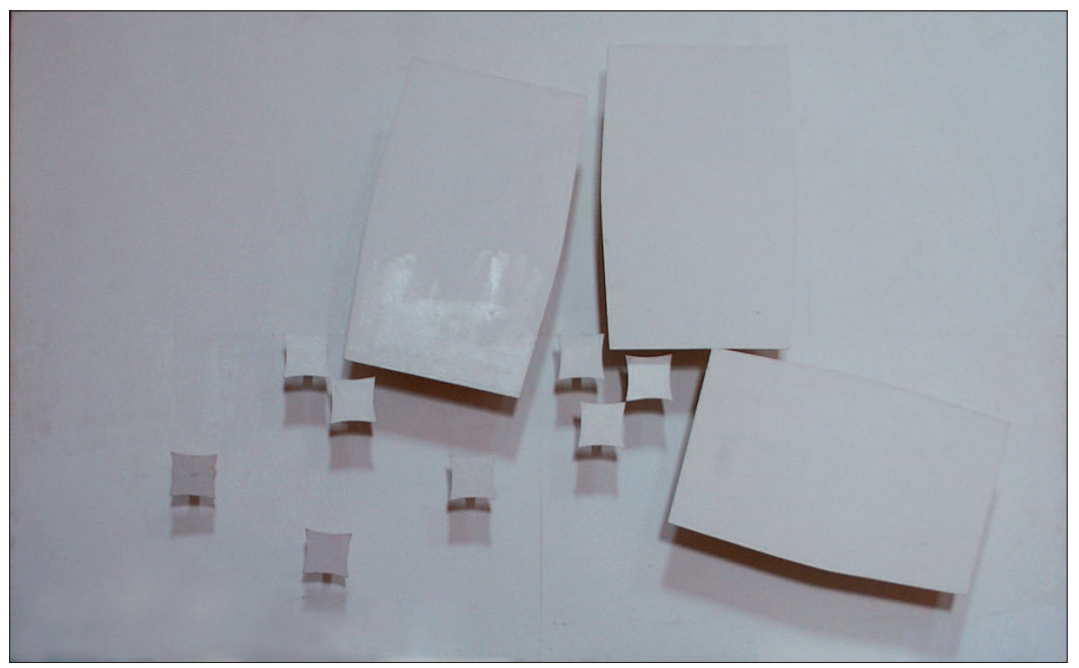

Il. 8. Relief bialy, 1964 r., Muzeum Architektury we Wrocławiu 


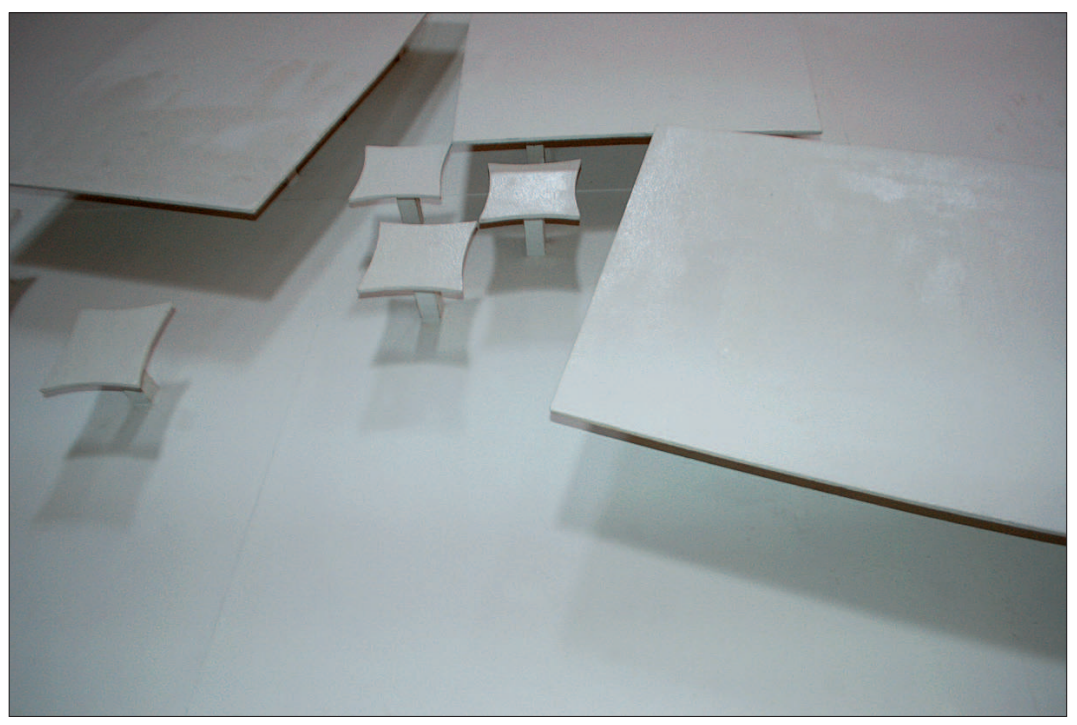

Il. 9. Zbliżenie fragmentu lica

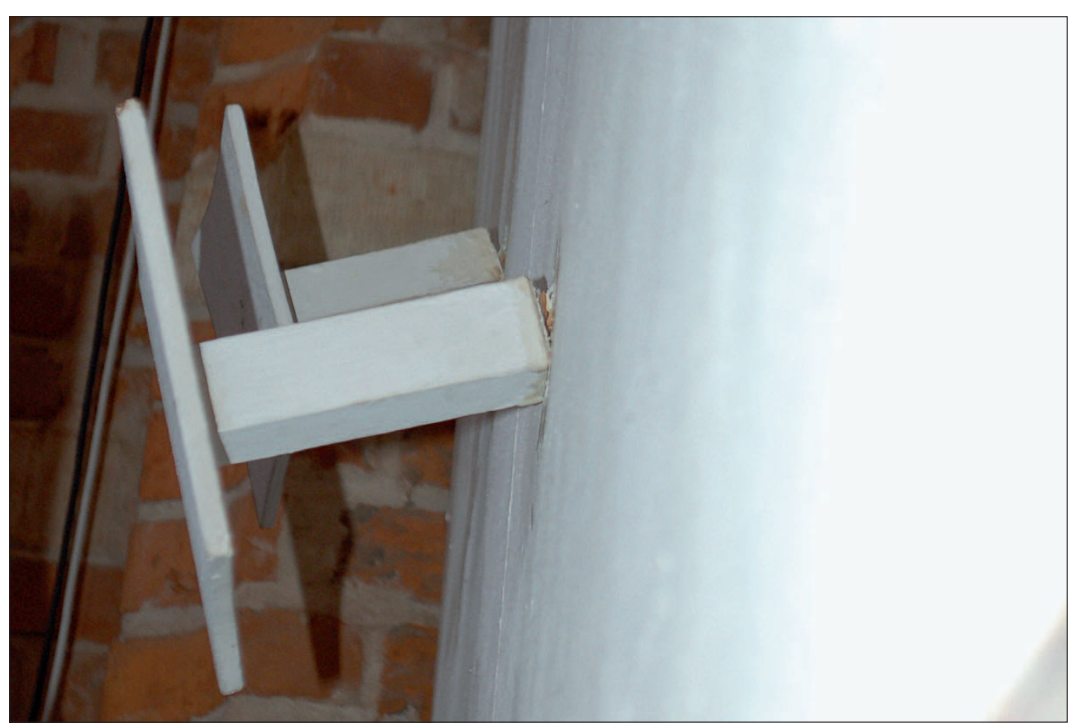

Il. 10. Zbliżenie fragmentu lica 


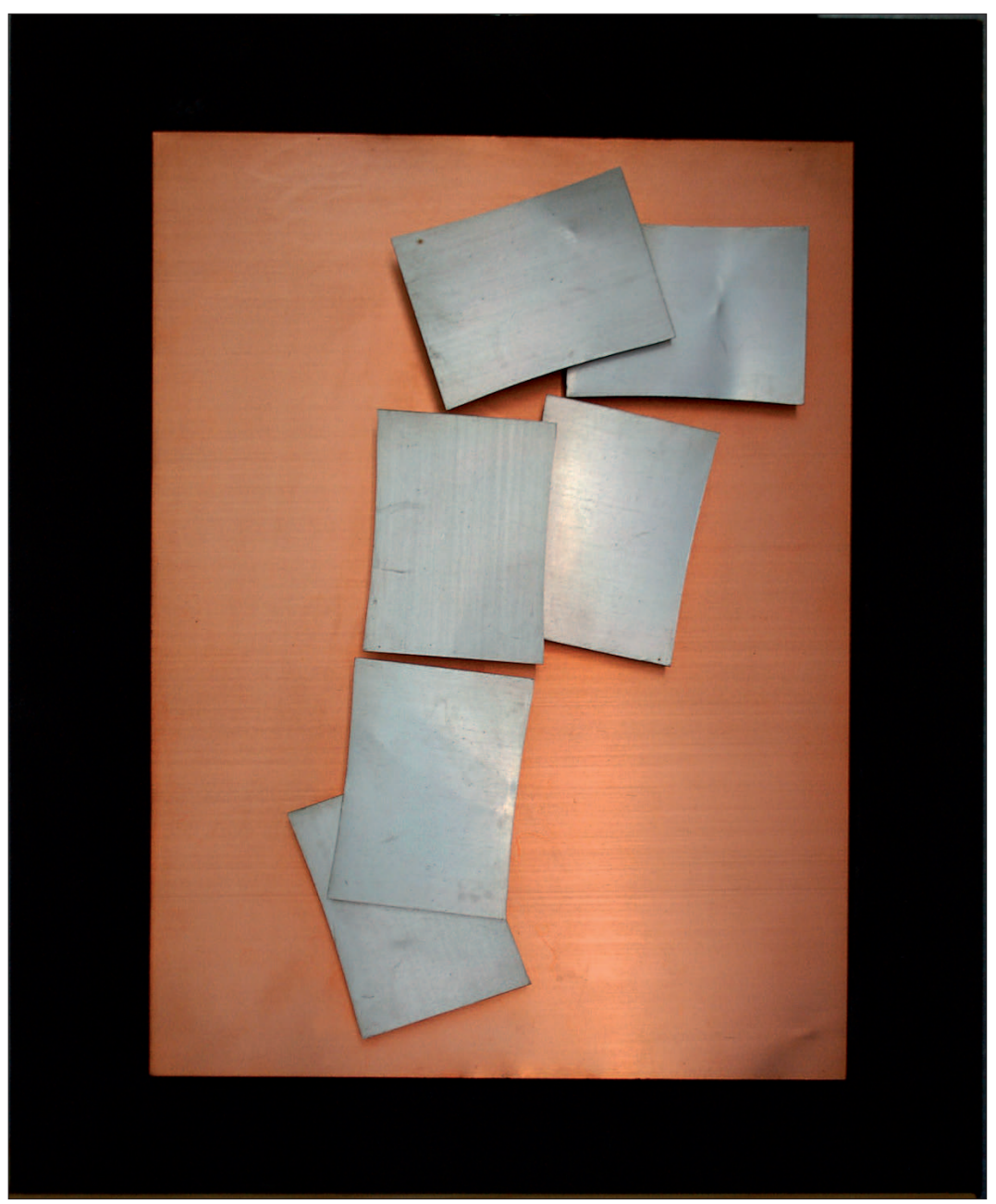

Il. 11. Relief różony, 1965 r., Muzeum Architektury we Wrocławiu 
[250]

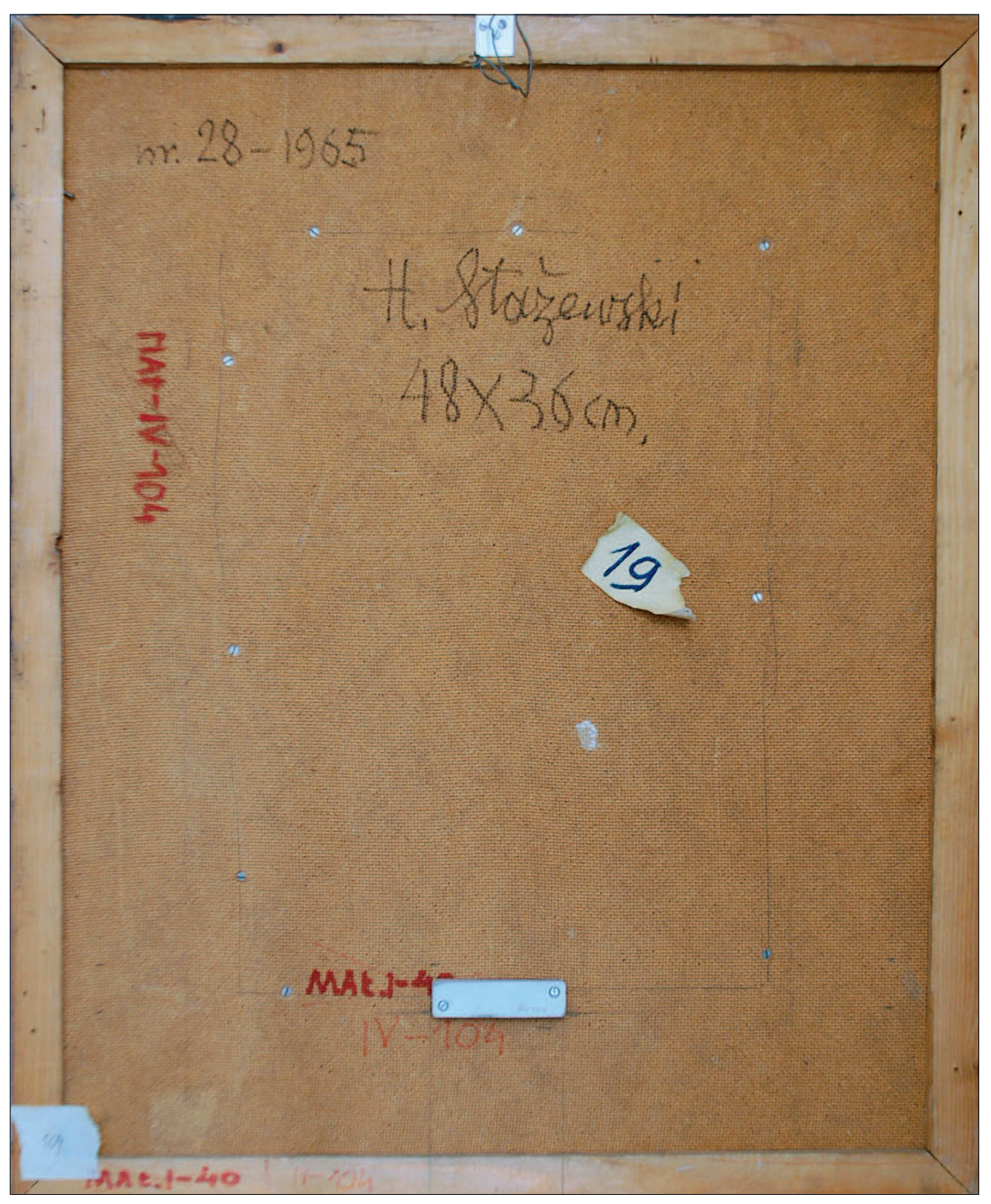

Il. 12. Relief róźony, odwrocie 


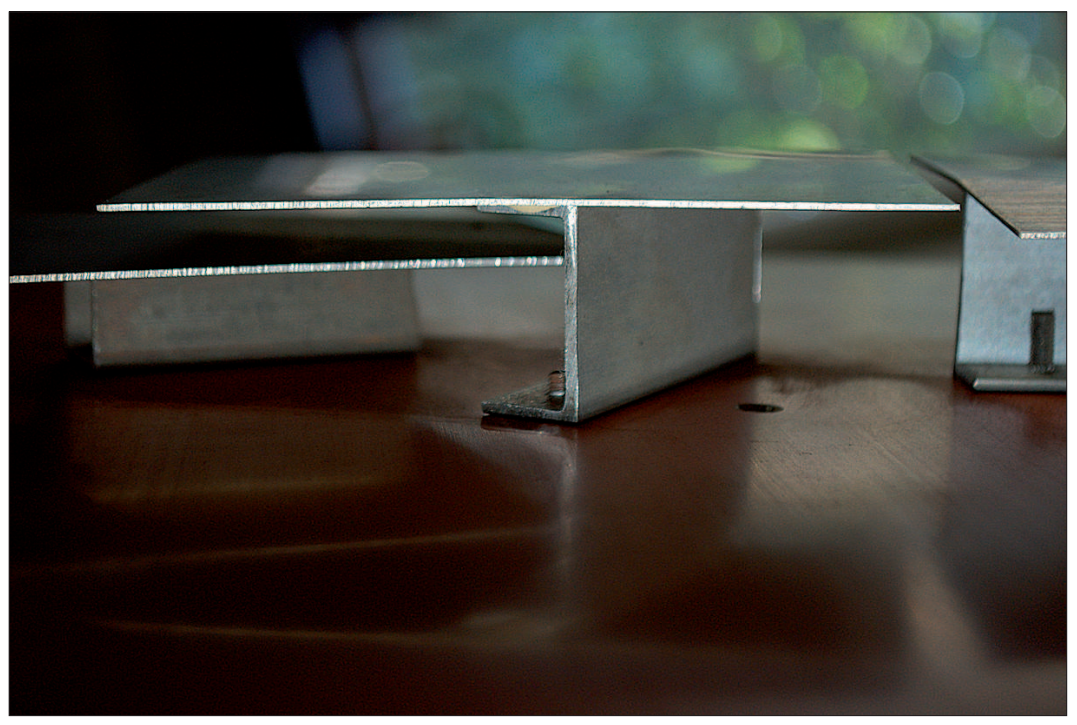

Il. 13. Zbliżenie fragmentu lica, widoczny sposób zamontowania figur geometrycznych

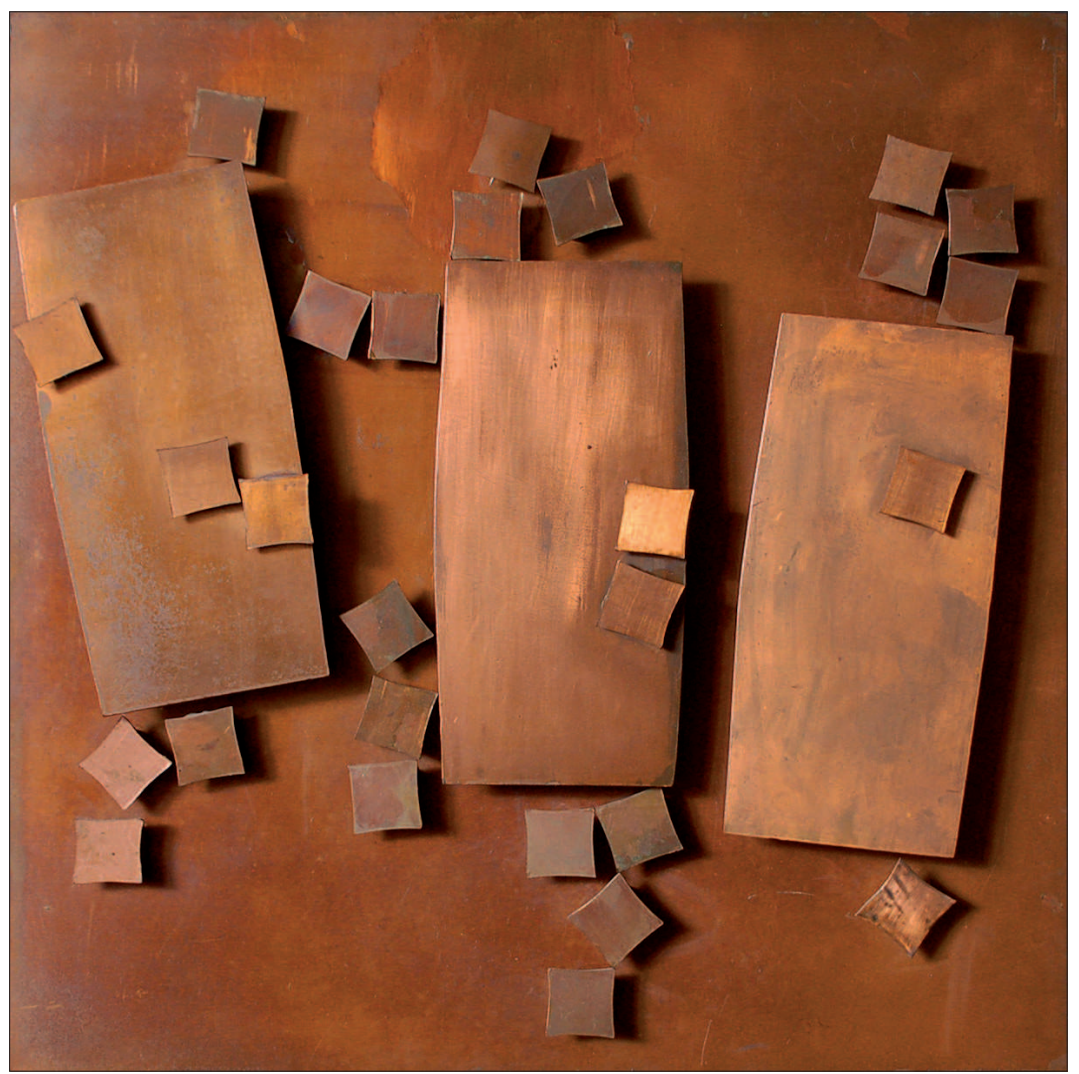

Il. 14. Relief 32, 1964 r., Muzeum Architektury we Wrocławiu 


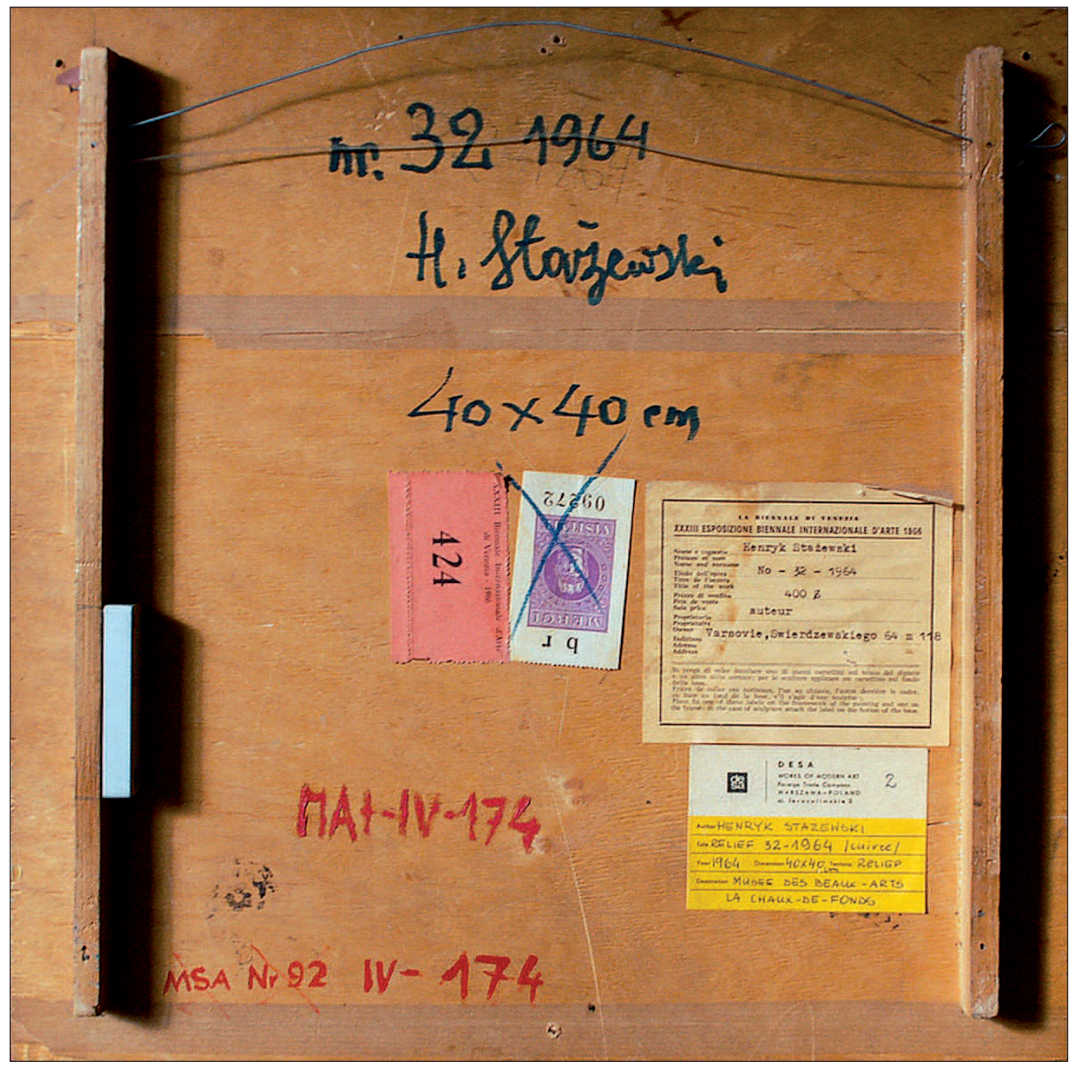

Il. 15. Relief 32, odwrocie

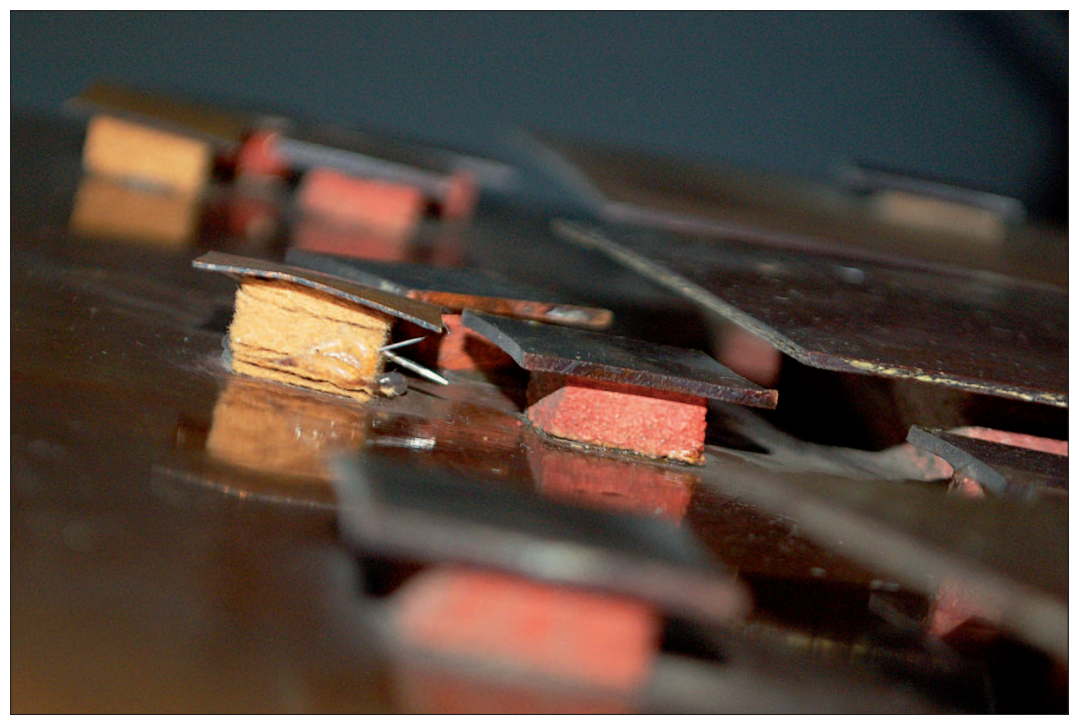

Il. 16. Zbliżenie fragmentu lica, widoczny sposób przymocowania figur geometrycznych 


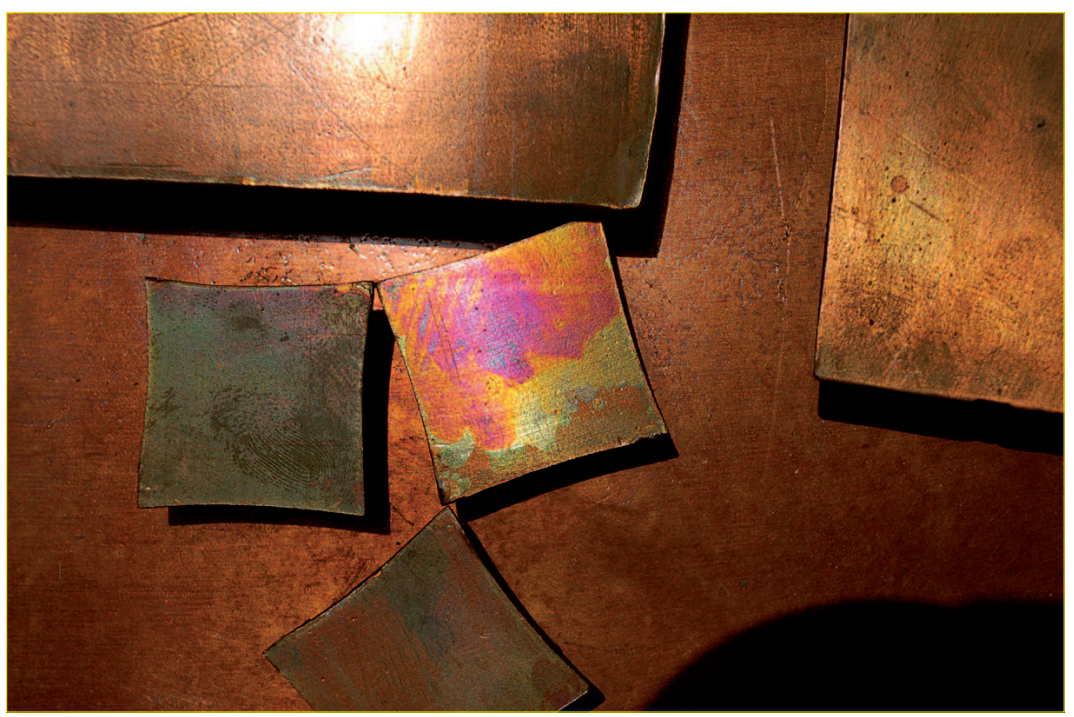

Il. 17. Zbliżenie fragmentu lica, widoczne zmiany kolorystyczne miedzianej folii

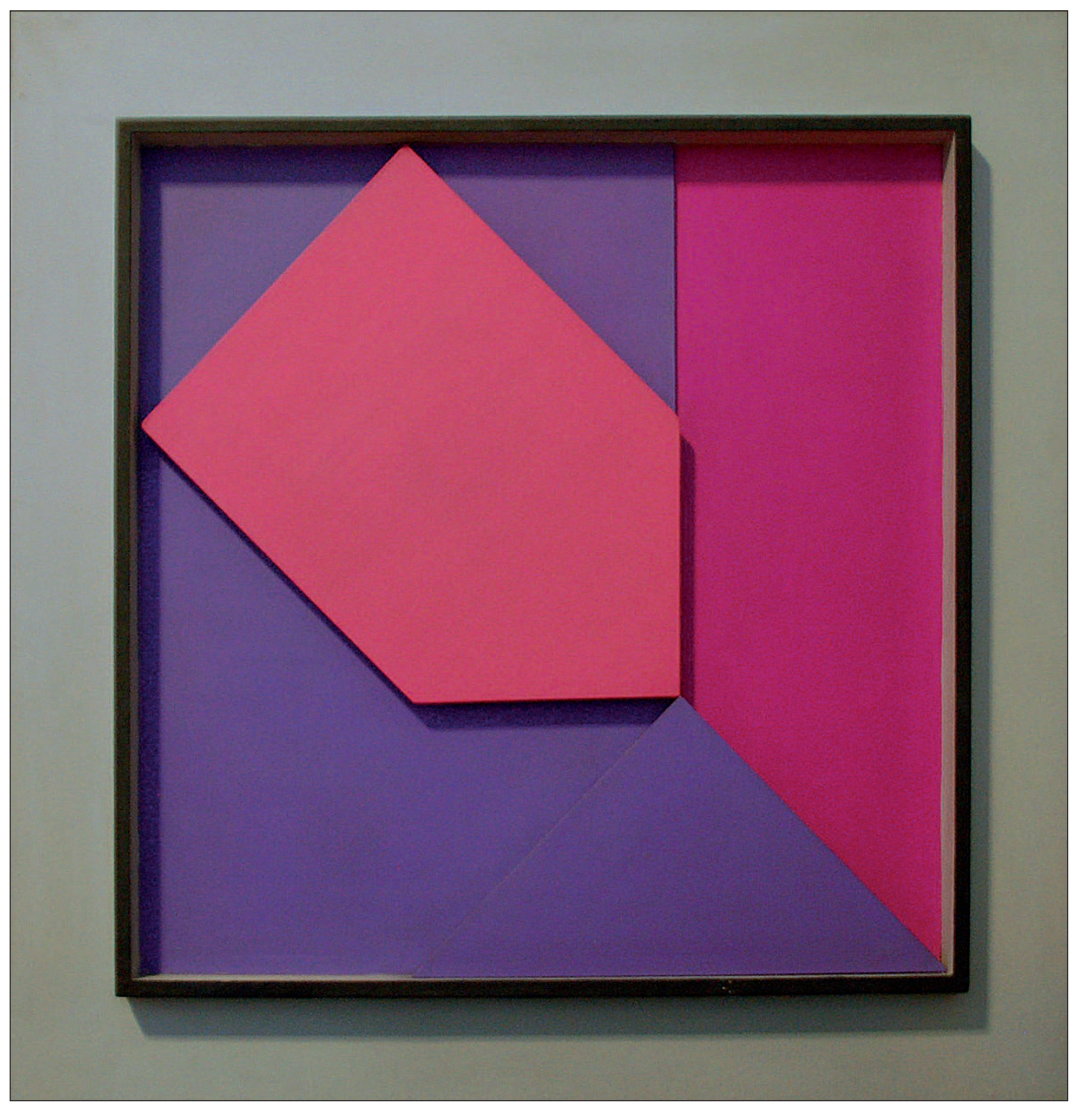

Il. 18. Relief 29, 1969 r., własność Muzeum Narodowego we Wrocławiu 


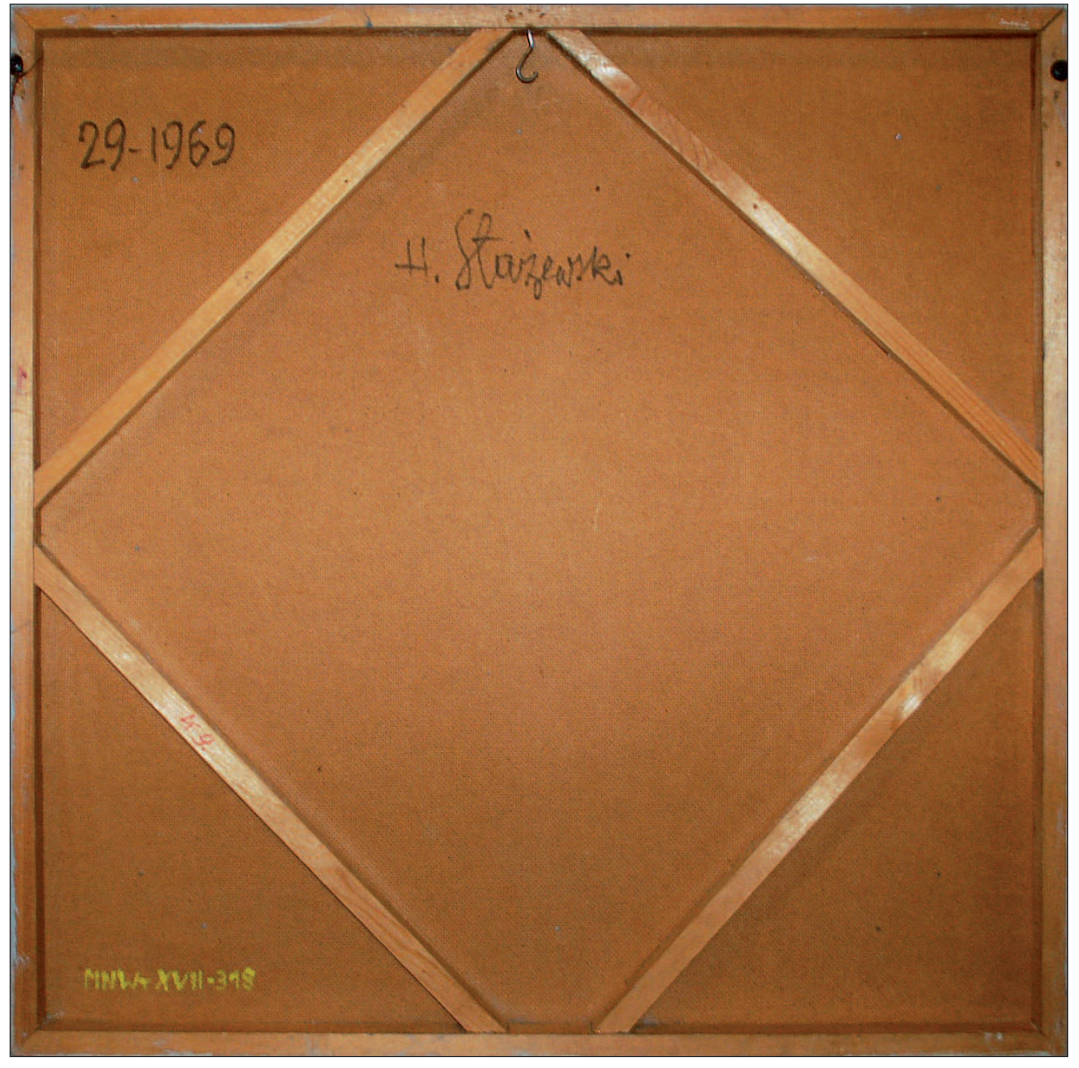

Il. 19. Relief 29, odwrocie

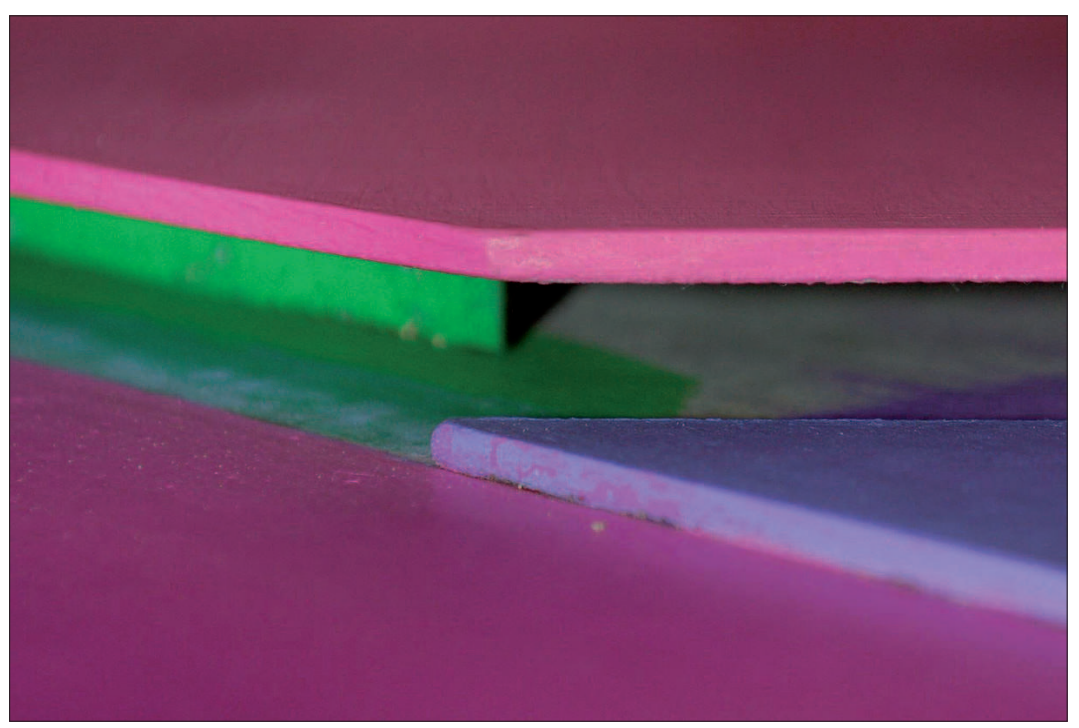

Il. 20. Zbliżenie fragmentu lica, w zagłębieniach reliefu widoczna wcześniejsza kolorystyka pracy 


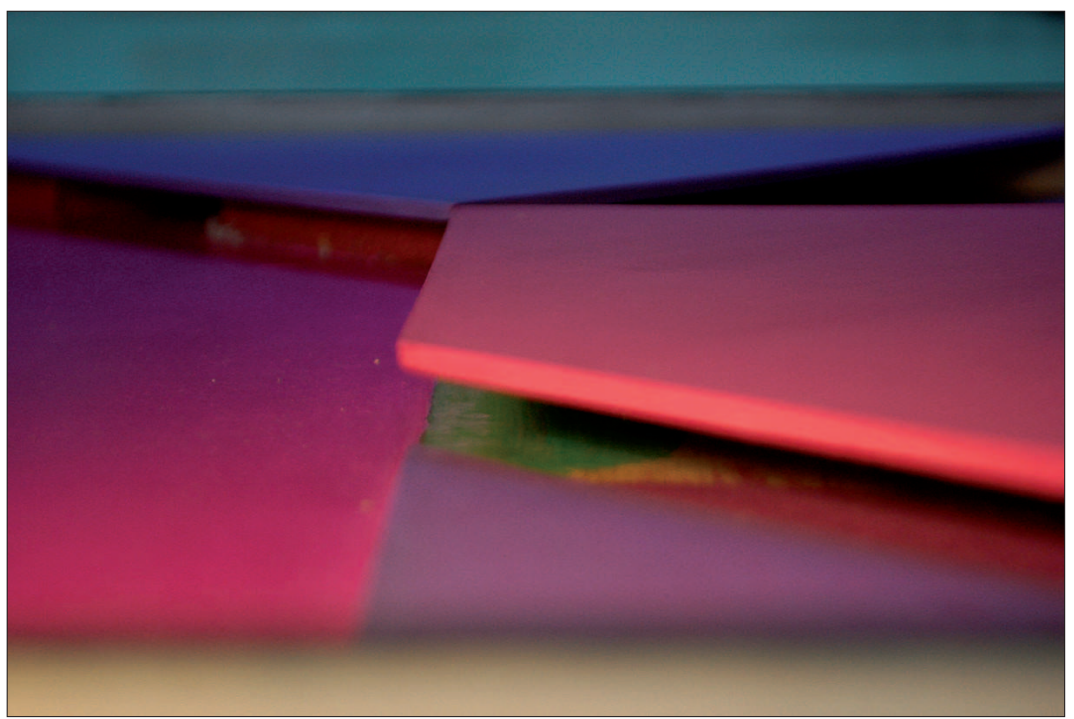

Il. 21. Zbliżenie fragmentu lica, w zagłębieniach reliefu widoczna wcześniejsza kolorystyka pracy

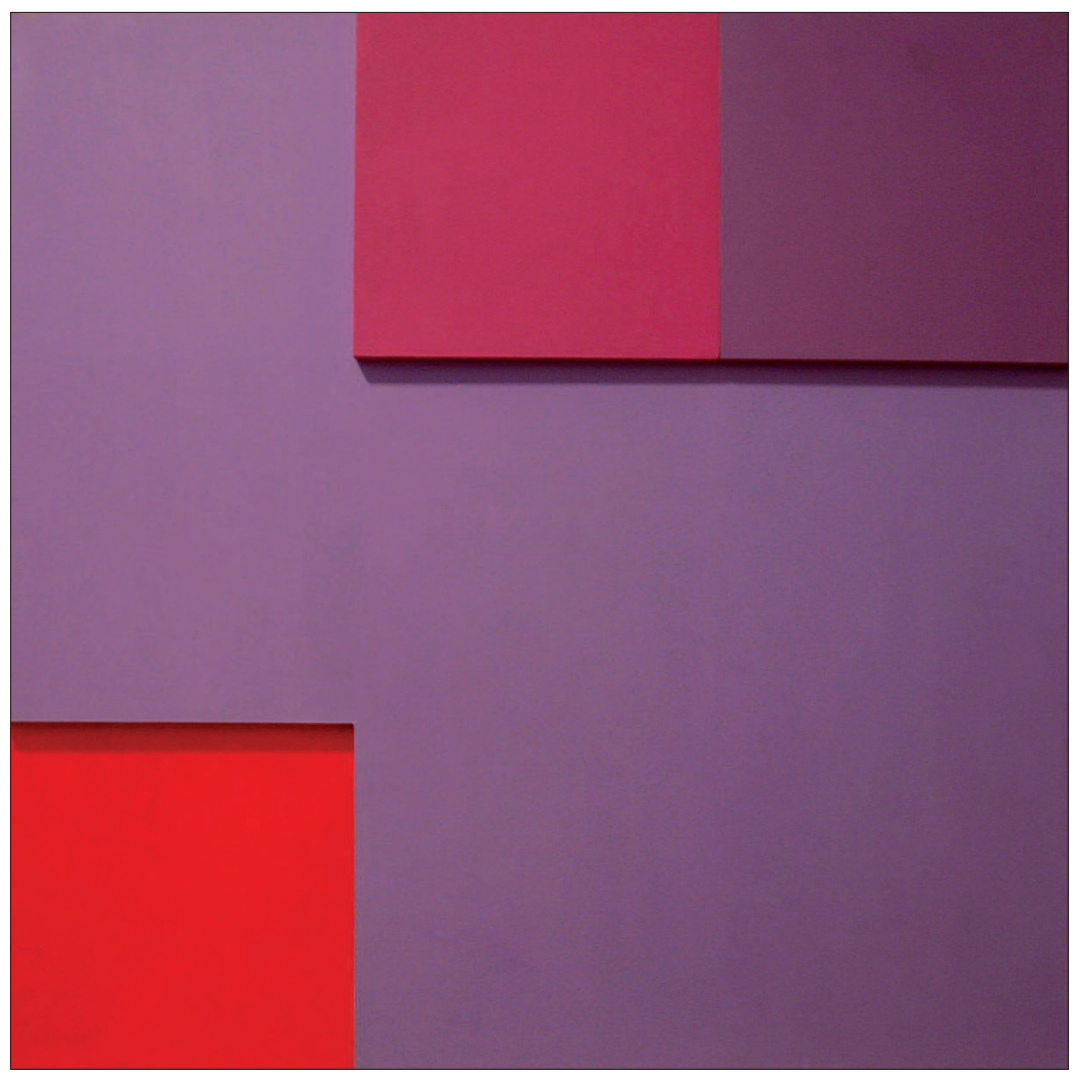

Il. 22. Relief 11, 1971 r., własność Muzeum Narodowego we Wrocławiu 
[256]

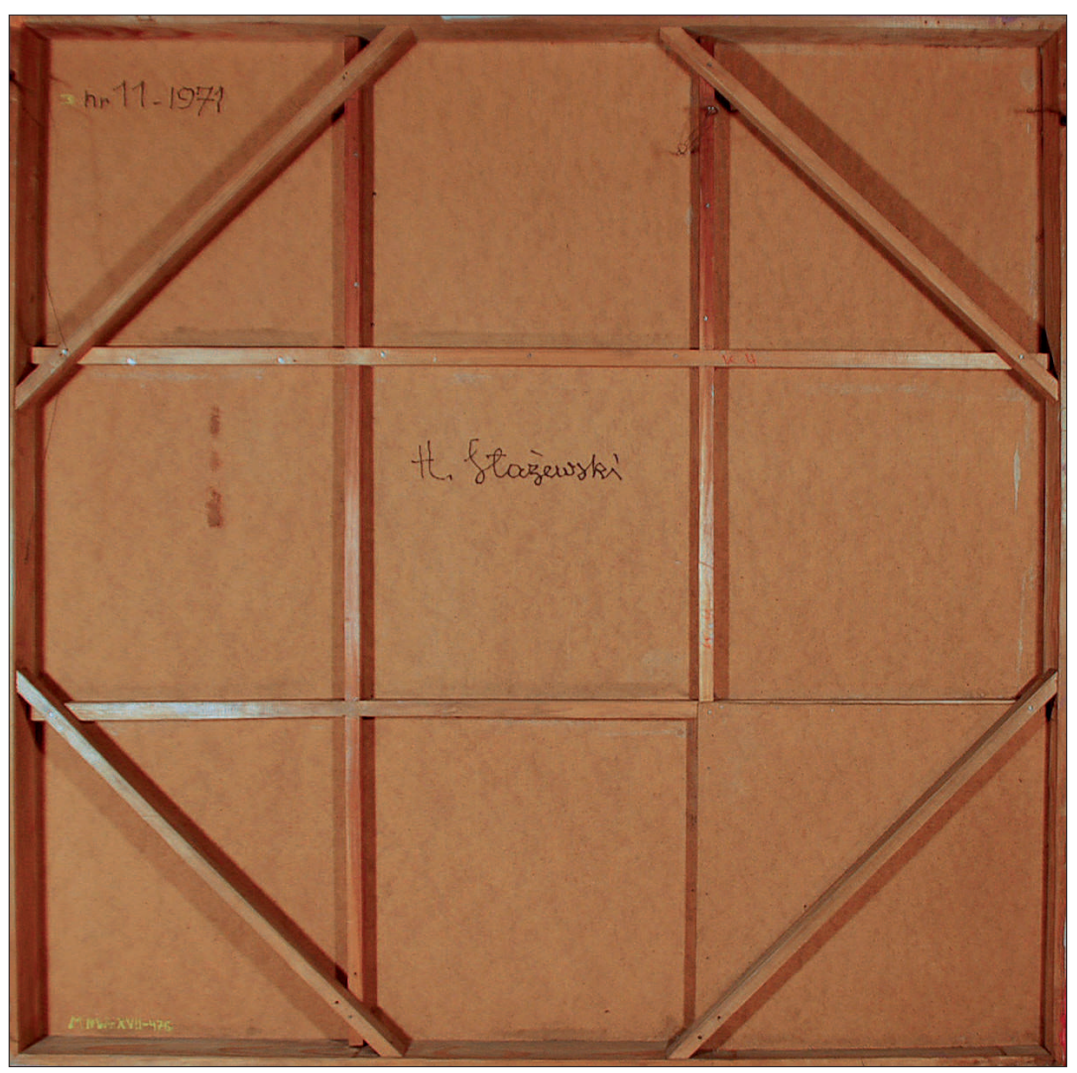

Il. 23. Relief 11, odwrocie 